\title{
Fatores motivacionais e modificações na vida dos mestrandos em contabilidade: os dois lados de uma mesma história
}

\author{
Motivational factors and changes in master's degree in accounting: the two sides of the \\ same story
}

Factores motivacionales y modificaciones en la vida de los maestros en contabilidad: los dos lados de una misma historia

\author{
Alison Martins Meurer \\ Mestre em Contabilidade pelo Programa de Pós-Graduação em Contabilidade (PPGCONT) da \\ Universidade Federal do Paraná (UFPR) \\ Professor-Colaborador na Universidade Estadual de Ponta Grossa (UEPG) \\ Endereço: Setor de Ciências Sociais Aplicadas \\ Av. Prefeito Lothário Meissner, 632 - UFPR - \\ CEP: 80210-170 - Curitiba - Paraná - Brasil \\ E-mail: alisonmmeurer@gmail.com \\ Telefone: (41) 3360-4193
}

\section{Antônio Nadson Mascarenhas Souza}

Mestre em Contabilidade pelo Programa de Pós-Graduação em Contabilidade (PPGCONT) da Universidade Federal do Paraná (UFPR)

Endereço: Setor de Ciências Sociais Aplicadas

Av. Prefeito Lothário Meissner, 632 - UFPR -

CEP: 80210-170 - Curitiba - Paraná - Brasil

E-mail: nadson.controladoria@gmail.com

Telefone: (41) 3360-4193

\section{Flaviano Costa}

Doutor em Controladoria e Contabilidade pela Faculdade de Economia, Administração e

Contabilidade da Universidade de São Paulo (USP)

Mestre em Contabilidade pelo Programa de Pós-Graduação em Contabilidade (PPGCONT) da Universidade Federal do Paraná (UFPR)

Endereço: Setor de Ciências Sociais Aplicadas

Av. Prefeito Lothário Meissner, 632 - UFPR -

CEP: 80210-170 - Curitiba - Paraná - Brasil

E-mail: flaviano@ufpr.br

Telefone: (41) 3360-4193

Artigo recebido em 13/12/2017. Revisado por pares em 05/02/2018. Reformulado em 20/03/2019. Recomendado para publicação em 20/03/2019 por Carlos Eduardo Facin Lavarda (Editor-Chefe). Publicado em 31/03/2019. 


\section{Resumo}

O ingresso no mestrado ocasiona modificações relevantes na vida dos alunos, seja nos âmbitos social, financeiro ou psicológico. As alterações da realidade frente aos novos compromissos podem gerar algumas consequências para os estudantes, e comprometer seu desempenho no curso. Nesse sentido, esta investigação buscou identificar as modificações (sociais, financeiras e psicológicas) ocorridas na vida dos alunos do mestrado em contabilidade após o ingresso no programa de pós-graduação. Sob a lente teórica das teorias do Capital Humano e da Autodeterminação foram identificadas as motivações que fomentaram o anseio e a tomada de decisão dos participantes para ingressarem no mestrado em contabilidade. Para a coleta das evidências foram realizadas entrevistas semiestruturadas e aplicado questionário em 12 mestrandos de uma instituição de ensino superior pública brasileira. O roteiro de entrevista foi submetido as validações propostas pela literatura especializada, sendo que os aspectos éticos foram observados pelos pesquisadores. A partir da análise dos discursos dos participantes foi possível identificar alguns achados relevantes e que devem ser considerados pelas coordenações dos cursos de pós-graduação brasileiros, pelos órgãos de fomento, professores, alunos e futuros candidatos. Primeiramente, os resultados apontam que em todos os aspectos elencados, financeiros e sociais, houveram modificações na vida da maioria dos participantes. As falas indicam que o fator financeiro é considerado um dos mais importantes e observado pelos mestrandos com vistas a conclusão do curso. Ademais, a sobrecarga de atividades e a falta de planejamento tanto em relação ao tempo como aos aspectos financeiros impactam psicologicamente os alunos. Percebeu-se também, que as motivações que levaram os estudantes a ingressarem no programa de pós-graduação alinham-se aos objetivos profissionais, mas estão também, fortemente relacionadas a satisfação pessoal e demais motivações intrínsecas. Destarte, considera-se que o estudo tenha dado voz aos mestrandos, na medida que inova por seu caráter qualitativo e análise em profundidade. Por fim, essa investigação é reflexo do retrato e desenho da pós-graduação existente no Brasil. Espera-se que os achados sirvam de embasamento para que as políticas de manutenção estudantil sejam mantidas e aprimoradas, bem como o próprio desenho da pós-graduação brasileira.

Palavras-Chave: Mestrado em contabilidade; Teoria do capital humano; Teoria da autodeterminação

\section{Abstract}

The admission on masters brings relevant modifications in the life of the students, in social, financial or psychological areas. The alteration of reality in the face of new commitments can have some consequences for students, and compromise their performance in the course. In this sense, this research sought to identify how changes (social, financial and psychological) occurred in the lives of students of the master's degree in accounting after joining the postgraduate program. Under the theoretical lens of Human Capital and Self-Determination theories were identified the motivations that fostered the participants' desire for and decision to enter the masters in accounting. To collect the evidences, we conducted semi-structured interviews and applied questionnaires in 12 Brazilian public higher education students. The interview script was submitted to the validations proposed by the specialized literature, and the ethical aspects were observed by the researchers. Based on the analysis of participants' speeches and possible knowledge, it is necessary to inform the coordination of Brazilian postgraduate courses, the development agencies, teachers, students and future candidates. First, the results point in all aspects, active and financial, there were modifications in the lives of the majority of participants. The speeches indicate that the financial factor is considered one of the most important and observed by the masters for the completion of the course. In addition, an overload of activities and a lack of planning both in relation to the time and financial aspects, psychologically impact the students. It was also noticed that motivations that led the students to enter the postgraduate program are aligned with professional goals, but are also strongly related to personal satisfaction and other intrinsic motivations. Thus, it is considered that the study gave voice to the masters, as it innovates for its qualitative character and in-depth analysis. Finally, this research is a reflection of the portrait and design of the postgraduate course in Brazil. It is hoped that the findings will serve as a basis for maintained and improved student maintenance policies, as well as the design of Brazilian postgraduate 
Fatores motivacionais e modificações na vida dos mestrandos em contabilidade: os dois lados de uma mesma história

studies.

Keywords: Master in accounting; Theory of human capital; Theory of self-determination

\section{Resumen}

El ingreso a la maestría ocasiona modificaciones relevantes en la vida de los alumnos, sea en el ámbito social, financiero o psicológico. Los cambios de la realidad frente a los nuevos compromisos pueden generar algunas consecuencias para los estudiantes, así como comprometer su desempeño en el curso. En este sentido, esta investigación buscó identificar las modificaciones (sociales, financieras y psicológicas) ocurridas en la vida de los alumnos de la maestría en contabilidad luego del ingreso al programa de postgrado. Bajo la lente teórica de las teorías del Capital Humano y de la Autodeterminación fueron identificadas las motivaciones que fomentaron el anhelo y la toma de decisión de los participantes para ingresar a la maestría en contabilidad. Para la recolección de las evidencias fueron realizadas entrevistas semiestructuradas y fue aplicado un cuestionario a 12 alumnos de maestría de una institución de enseñanza superior pública brasilera. La guía de entrevista fue sometida a las validaciones propuestas por la literatura especializada, siendo que los aspectos éticos fueron observados por los investigadores. A partir del análisis de los discursos de los participantes fue posible identificar algunos hallazgos relevantes y que deben ser considerados por las coordinaciones de los cursos de postgrado brasileros, por los órganos de fomento, profesores, alumnos y futuros candidatos. En primer lugar, los resultados apuntan que en todos los aspectos enumerados, financieros y sociales, hubo cambios en la vida de la mayoría de los participantes. Las declaraciones indican que el factor financiero es considerado uno de los más importantes y observado por los alumnos de maestría con miras a la conclusión del curso. Además, la sobrecarga de actividades y la falta de planificación tanto en relación al tiempo como a los aspectos financieros, impactan psicológicamente a los alumnos. Se percibió también que las motivaciones que llevaron a los estudiantes a ingresar en el programa de postgrado se alinean a los objetivos profesionales, pero también están fuertemente relacionadas con la satisfacción personal y demás motivaciones intrínsecas. De este modo, se considera que el estudio ha dado voz a los estudiantes de maestría, en la medida que innova por su carácter cualitativo y análisis en profundidad. Por último, esta investigación es reflejo del retrato y el diseño del postgrado existente en Brasil. Se espera que los hallazgos sirvan de base para que las políticas de mantenimiento estudiantil sean mantenidas y perfeccionadas, así como el propio diseño del postgrado brasilero.

Palabras clave: Maestría en contabilidad; Teoría del capital humano; Teoría de la autodeterminación

\section{Introdução}

A Teoria do Capital Humano expõe que os investimentos em educação aumentam a expectativa de maximização do valor pessoal e fomentam maiores níveis de rentabilidade, empregabilidade e produtividade (SCHULTZ, 1959; BECKER, 1962). Assim, a motivação para investir em educação ou capacitação advém das oportunidades e pressões exclusivas do ambiente externo.

Entretanto, as motivações que fomentam a capacitação e formação vão além dos aspectos extrínsecos, mas também abrangem fatores intrínsecos ao sujeito. A partir do século XX estudos com foco nos fatores pessoais motivacionais cresceram significativamente. Diversos pesquisadores publicaram trabalhos e formularam teorias a respeito do assunto com o intuito de identificar os fatores que motivam as ações pessoais (FREUD, 1914; HULL, 1943; MASLOW, 1943; BERLYNE, 1950; HARLOW, 1950; WHITE, 1959; DECI, 1980; DECI; RYAN, 1980; SHAPIRO, 1981; RYAN, 1982).

Dentre essas pesquisas destaca-se a de Deci e Ryan (1980) que formularam a Teoria da Autodeterminação com intuito de estudar os aspectos intrínsecos e extrínsecos que motivam as atitudes pessoais (DECI; RYAN, 1985). Sendo os intrínsecos aqueles ligados à satisfação e bem-estar e os extrínsecos relacionados ao ambiente externo, como compensação, punição, fatores de aprovação, autoestima, vergonha e necessidade (DECI; RYAN, 1980).

A partir de ambos arcabouços teóricos, alguns pesquisadores têm investigado os fatores 
motivacionais e expectativas para cursar mestrado stricto sensu nas diversas áreas do conhecimento. Por exemplo, na Engenharia de Produção tem-se o trabalho de Andrade et al. (2011); na área da saúde, especificamente em Enfermagem, Frederico-Ferreira e Loureiro (2013) trazem suas contribuições; e nas ciências exatas, em Matemática, por Araújo e Amaral (2005). Já nas Ciências Sociais Aplicadas, especificamente em Ciências Contábeis, alguns trabalhos foram desenvolvidos com vistas a análise das motivações, influências, consequências e expectativas na predição dos alunos em cursar pós-graduação stricto sensu em contabilidade (CARVALHO et al., 2003; LEITE FILHO; RODRIGUEZ, 2006; CUNHA, 2007; MARTINS; MONTE, 2010; AVELINO; CUNHA; NASCIMENTO, 2013; DURSO et al., 2016; BARTH; ENSSLIN; BORGERT, 2016).

As pesquisas de Carvalho et al. (2003), Leite Filho e Rodriguez (2006), Cunha (2007), Martins e Monte (2010) e Barth, Ensslin e Borgert (2016) analisaram a percepção dos egressos quanto aos benefícios pessoais e atendimento das expectativas em relação aos programas de pós-graduação. Em contrapartida, Avelino, Cunha e Nascimento (2013) e Durso et al. (2016) identificaram os fatores e níveis motivacionais dos alunos de graduação em cursar pós-graduação nível stricto sensu. Essas pesquisas trouxeram contribuições para a área temática, pois se tratando da análise dos egressos, os achados deste tipo de estudo fornecem evidências que embasam as tomadas de decisões, seja por parte do Governo, do programa ou do candidato ao curso (BARTH; ENSSLIN; BORGERT, 2016). Já a análise dos potenciais candidatos possibilita mapear a motivação e traçar o perfil dos futuros alunos.

Outra perspectiva de abordagem acerca da temática é abordada por Borges, Faria e Gil (2007) que a partir da aplicação da metodologia Decisão, Exceção e Quantificação (DEQ), que é utilizada em processos de tomada de decisão em ambientes empresariais foram identificadas as principais falhas e fatores críticos na autogestão dos mestrandos em contabilidade. As discussões teóricas fomentam reflexões das escolhas efetuadas quando decide-se cursar mestrado, além dos fatores que podem influenciar no sucesso ou fracasso do aluno no curso, bem como as modificações que há na vida do acadêmico após o ingresso no programa.

Nesse contexto, Avelino, Cunha e Nascimento (2013) recomendam analisar a motivação de alunos que efetivamente ingressaram na pós-graduação stricto sensu. Borges, Faria e Gil (2007) destacam a necessidade de ir além das discussões teóricas e verificar na prática as modificações que ocorrem na vida dos acadêmicos após o ingresso no mestrado.

Portanto, reconhecendo a importância do tema e sob a luz da Teoria do Capital Humano e da Teoria da Autodeterminação essa pesquisa busca investigar: quais as modificações (sociais, financeiras e psicológicas) ocorridas na vida dos alunos de mestrado em contabilidade após o ingresso no programa de pós-graduação? E quais os fatores que motivaram os mestrandos a ingressarem no curso de pós-graduação em contabilidade? O objetivo da pesquisa está na verificação das modificações sociais, financeiras e psicológicas que ocorreram na vida dos mestrandos após o ingresso no curso e os fatores que motivaram esses alunos a cursar pós-graduação em contabilidade.

O estudo visa enriquecer a partir das descobertas práticas os resultados expostos no ensaio de Borges, Faria e Gil (2007). Nota-se a relevância de verificar os fatores que motivam os mestrandos, e possivelmente futuros docentes, a ingressar nessa carreira, visto a importância da pós-graduação para ciência nacional e sistema educacional. Nessa ótica, estudos que abrangem contextos educacionais mostram-se importantes, pois a educação auxilia na formação de cidadãos capazes de refletir, criticar e criar novos meios que modifiquem o estágio de uma sociedade (SCHULTZ, 1971; ANDERE; ARAÚJO, 2008). É oportuno estudar tais aspectos para que sejam subsidiadas informações para aqueles que desconhecem o contexto da pós-graduação stricto sensu e para contribuir com o processo de desenvolvimento e gestão estudantil dos programas a partir das percepções dos discentes (BORGES; FARIA; GIL, 2007).

Esta investigação fornece avanços em relação aos trabalhos de Carvalho et al. (2003), Leite Filho e Rodriguez (2006), Avelino, Cunha e Nascimento (2013) e Durso et al. (2016) por investigar alunos efetivamente matriculados em um programa de mestrado, o que permite analisar os fatores que 
motivaram o ingresso no programa. Em relação aos estudos de Cunha (2007), Martins e Monte (2010) e Barth, Ensslin e Borgert (2016) a pesquisa verificará além dos fatores motivacionais, as mudanças e dificuldades que ocorrem na vida dos alunos que almejam o título de mestre. Ademais, este estudo busca mostrar a percepção dos estudantes por meio da abordagem qualitativa dando voz aos mestrandos e fornecendo introspecções para pesquisas futuras.

\section{Fundamentação Teórica}

O primeiro tópico objetiva dispor elementos que permitam refletir sobre a importância da compreensão de: quais as modificações (sociais, financeiras e psicológicas) ocorridas na vida dos alunos do mestrado em contabilidade após o ingresso no programa de pós-graduação?

\subsection{Modificações na Vida dos Pós-Graduandos}

Borges, Faria e Gil (2007) relatam que inúmeros fatores influenciam a decisão de cursar mestrado ou doutorado, sendo que estes vão desde a ampliação do conhecimento até a maximização da remuneração. Os autores citam que da mesma forma diversos fatores podem comprometer o sucesso do aluno no decorrer de sua trajetória no programa, como por exemplo, recursos financeiros, materiais, humanos e tecnológicos. Além disso, há pressões oficiais inerentes a necessidade do cumprimento de prazos das atividades e conclusão do curso que afetam a trajetória acadêmica do discente.

Mesmo assim, há na literatura indícios que apontam que maior parte dos mestrandos acreditam que conseguirão cumprir os prazos das tarefas estabelecidas. Para que isso ocorra é importante que durante o mestrado haja dedicação, responsabilidade, transparência e ética por parte dos discentes, pois a ausência dessas atitudes pode fomentar o rompimento de elos ou o desenvolvimento de situações que comprometam a conclusão do curso. No que tange à dedicação, os alunos devem ter consciência que o enfoque da pós-graduação stricto sensu é a pesquisa e à docência. Para que os trabalhos sejam efetuados com qualidade e os estudos sejam proveitosos necessita-se de alto grau de independência e automotivação. $\mathrm{O}$ aluno deve ser capaz de conciliar as atividades do mestrado com sua vida social, visto que no decorrer do curso tende haver distanciamento das atividades sociais, pessoais, familiares e conjugais devido ao mestrado, podendo gerar sentimento de desmotivação que pode comprometer seu desempenho acadêmico. (BORGES; FARIA; GIL, 2007).

Percebe-se que a pós-graduação pode gerar custos aos estudantes, sendo que estes englobam aspectos além dos monetários. Barth (2015) verificou junto a uma amostra composta por 46 mestres, 32 mestrandos e 13 evadidos do Programa de Pós-Graduação em Contabilidade da Universidade Federal de Santa Catarina (UFSC) que 67,39\% dos mestres tiveram desgastes em relacionamentos interpessoais durante o mestrado; $89,13 \%$ diminuíram o convívio familiar durante o período do curso; $69,57 \%$ relataram dificuldades em conciliar o mestrado com o trabalho; $86,96 \%$ apontaram que se dedicaram de forma exagerada ao curso; $84,78 \%$ sofreram com estresse e pressões psicológicas; $84,78 \%$ diminuíram o tempo gasto com lazer; e $82,61 \%$ acabaram diminuindo os cuidados com a saúde (exercícios físicos e alimentação). Sendo que esses elementos auxiliam a desmotivação.

Em termos financeiros, normalmente há decréscimo na renda dos discentes após o ingresso no curso. Torna-se essencial que antes de ingressar em um programa de pós-graduação haja planejamento financeiro, visto que nem todas as instituições são públicas ou oferecem bolsa de estudos. Ademais, mesmo havendo gratuidade na mensalidade, há outros custos durante o mestrado, sejam eles com fotocópias, impressões, diárias, gastos com deslocamento, despesas com mudança de região (se for o caso), moradia, alimentação, entre outras (BORGES; FARIA; GIL, 2007; BARTH, 2015).

Atentar-se aos aspectos financeiros é importante, pois tal elemento é essencial na continuidade do curso. Tal fato pôde ser comprovado por Barth (2015) em que dos 13 alunos evadidos do programa de mestrado, 11 apontaram que as dificuldades financeiras afetaram sua decisão, sendo o elemento com maior número de apontamentos. Percebe-se que manter o equilíbrio entre as várias facetas inerentes a vida acadêmica e pessoal torna-se necessário, tanto para que o aluno não fique desmotivado, quanto para não haver consequências psicológicas que afetam a saúde física, comportamental e o desempenho das tarefas. Logo, a decisão de ingressar no mestrado apresenta-se como um projeto que está exposto a riscos, e como citado por Borges, Faria e Gil (2007) e Barth (2015), necessita de planejamento em 
termos monetários, de tempo e preparação psicológica.

Compreender os fatores que motivam os discentes a ingressarem na pós-graduação é relevante por permitir mapear seus objetivos, expectativas e perspectivas em relação ao mestrado. Nesse sentido, o próximo tópico traz introspecções e fundamentos teóricos que auxiliam a responder a seguinte inquietação: quais os fatores que motivaram os mestrandos a ingressarem no curso de pós-graduação em contabilidade?

\subsection{Teoria da Autodeterminação e Teoria do Capital Humano}

A Teoria da Autodeterminação de Deci e Ryan (1980) busca identificar os fatores intrínsecos e extrínsecos que fomentam a atitude e o comportamento humano. Sendo os intrínsecos ligados a satisfação e bem-estar e os extrínsecos relacionados ao ambiente externo, como compensação, punição, fatores de aprovação, autoestima, vergonha e necessidade (DECI; RYAN, 1980).

A Teoria da Autodeterminação se diferencia das demais teorias que abordam o processo motivacional, pois não trata a motivação como um comportamento unitário, mas a segrega em níveis categóricos que permitem identificar os fatores que são mais importantes na predição de determinados comportamentos (Durso et al., 2016). Nessa abordagem são detalhadas as diferentes formas de motivação e fatores que impedem ou promovem a internalização e integração da regulação no comportamento (DECI; RYAN, 1985). Na

Figura 1 é exposto o continuum de autodeterminação proposto por Decy e Ryan (2000).

Figura 1. Continuum da Teoria da Autodeterminação

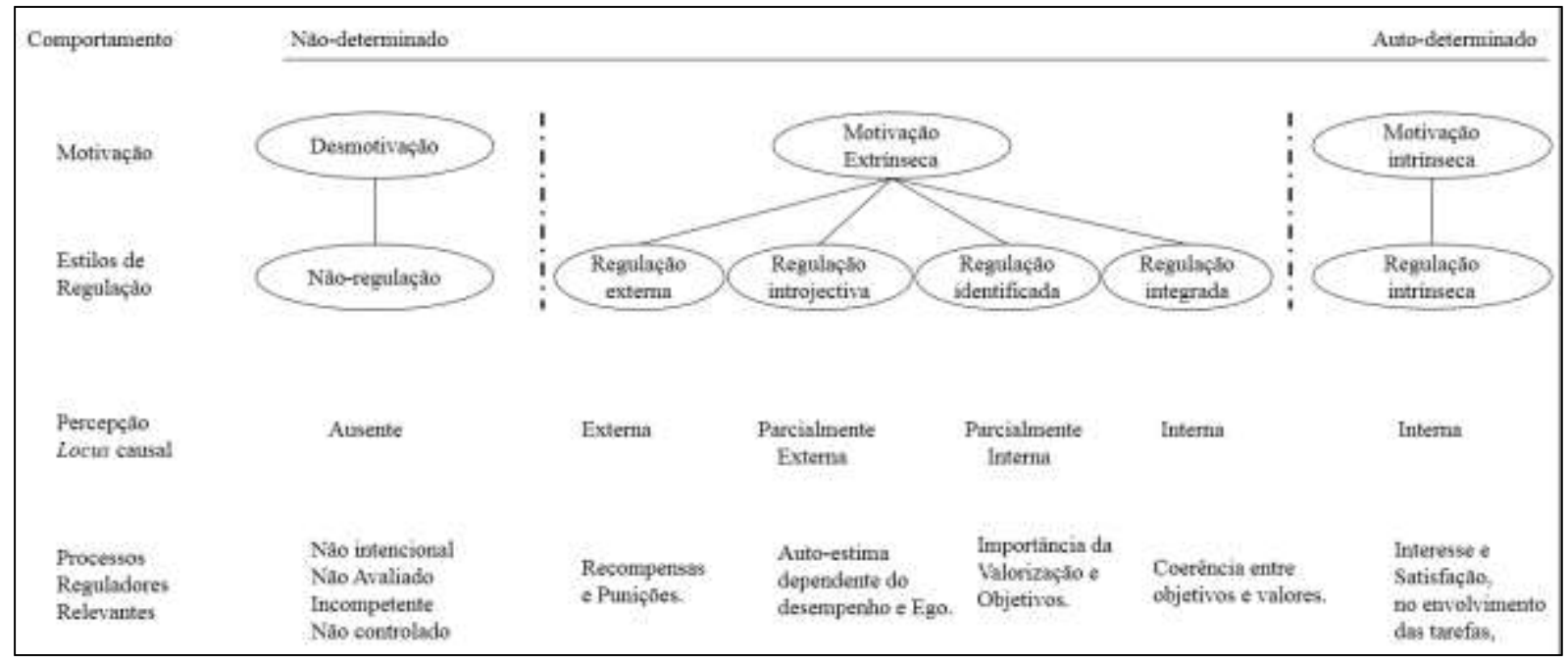

Fonte: Adaptado de Deci e Ryan (2000).

Ao analisar os fatores motivacionais nota-se a influência do ambiente externo, representado pela motivação extrínseca. Normalmente essas influências exteriores sobre as ações do sujeito surgem no início da adolescência por meio de pressões sociais ou pelo surgimento de novas responsabilidades. Em contrapartida, a motivação intrínseca está relacionada aos interesses e satisfação que o indivíduo possui internamente na realização de uma tarefa, sem que as pressões do ambiente externo sejam fatores determinantes para sua ação (DECI; RYAN, 2000). Nesta concepção, estudantes intrinsecamente motivados tendem a ter melhor desempenho acadêmico, pois a tarefa não é vista somente como uma obrigação, mas também como algo satisfatório (DURSO et al., 2016).

A Teoria do Capital Humano é outra abordagem que auxilia a explicar aspectos motivacionais quanto as ações das pessoas referente a investimentos em educação. Essa teoria é derivada da economia e foi proposta por Schultz (1959) e Becker (1962). A partir de uma visão macroeconômica essa perspectiva teórica propõe que os investimentos relacionados a educação auxiliam na maximização da capacidade técnica e produtiva dos países (SCHULTZ, 1971). Quando analisados os aspectos 
econômicos individuais, os investimentos em educação e capacitação possibilitam a elevação dos postos de empregabilidade, aumento de potenciais rendimentos pessoais e produtividade (BECKER, 1962). Assim, o capital humano pode ser entendido como o conjunto de conhecimentos, talentos e habilidades de um indivíduo, que são utilizados na execução de uma determinada tarefa (IWAMOTO; TAKAHASHI, 2015).

Para Barth, Ensslin e Borgert (2016) o núcleo central da Teoria do Capital Humano abarca-se na explicação da relação entre educação, trabalho e renda. Para os autores, o aumento do nível educacional fomenta incremento de habilidades e conhecimentos, que expandem os níveis de empregabilidade, aumentam a produção e consequentemente geram maiores rendas. Nessa ótica, a motivação advém de pressões ou oportunidades existentes no ambiente externo, caracterizando uma motivação extrínseca referente a decisão de investir em educação e capacitação. A partir da verificação dos aspectos similares entre ambas as teorias foram definidos os construtos motivacionais utilizados neste estudo e que são expostos no Quadro 1.

Quadro 1 - Construtos da pesquisa

\begin{tabular}{|c|c|c|c|}
\hline Construto & Definição & Variáveis & Referência \\
\hline \multirow{4}{*}{$\begin{array}{c}\text { Motivação } \\
\text { Intrínseca (MI) }\end{array}$} & \multirow{4}{*}{$\begin{array}{l}\text { Fatores internos que influenciam o } \\
\text { indivíduo a realizar uma } \\
\text { determinada ação ou ter um certo } \\
\text { comportamento. }\end{array}$} & Satisfação pessoal & \multirow{6}{*}{$\begin{array}{c}\text { Decy e Ryan } \\
\text { (1985). }\end{array}$} \\
\hline & & Efetividade & \\
\hline & & Autonomia & \\
\hline & & Aumento conhecimento & \\
\hline \multirow{4}{*}{$\begin{array}{c}\text { Motivação } \\
\text { Extrínseca (ME) }\end{array}$} & \multirow{4}{*}{$\begin{array}{c}\text { Fatores externos que influenciam o } \\
\text { comportamento ou a realização de } \\
\text { uma determinada ação, estão ligados } \\
\text { a fatores ambientais, ou seja, } \\
\text { externos. }\end{array}$} & Imposição & \\
\hline & & Ego/Autoestima/Status & \\
\hline & & Recompensa & \multirow{2}{*}{$\begin{array}{c}\text { Decy e Ryan } \\
(1985) ; \text { Schultz } \\
(1971) \text {. } \\
\end{array}$} \\
\hline & & Crescimento profissional & \\
\hline
\end{tabular}

Fonte: Elaborado pelos autores com base em Decy e Ryan (1985) e Schultz (1971).

Em relação às variáveis, estudos empíricos (AVELINO; CUNHA; NASCIMENTO, 2013; BARTH, 2015; BARTH; ENSSLIN; BORGERT, 2016; DURSO et al., 2016) têm vinculada a motivação intrínseca a satisfação pessoal, efetividade, autonomia e aumento do conhecimento e a motivação extrínseca a imposição, ego/autoestima/status, recompensa e crescimento profissional. Cabe destacar que nesta pesquisa não é abordada a dimensão de desmotivação, visto que um dos objetivos do estudo consiste em verificar os aspectos que motivaram os estudantes a ingressarem no mestrado em contabilidade, e não seu estágio de motivação ou desmotivação.

Em relação aos estudos anteriores, Leite Filho e Rodriguez (2006) verificaram junto a 65 alunos de graduação em Ciências Contábeis que a motivação para cursar pós-graduação está relacionada aos benefícios pessoais e financeiros que esses títulos podem proporcionar a quem os detém. Avelino, Cunha e Nascimento (2013) também analisaram alunos de graduação. A amostra foi composta por 50 alunos de uma Instituição de Ensino Superior (IES) pública e outros 50 alunos oriundos de duas IES privadas. Os achados indicaram que os alunos acreditam que a pós-graduação possibilita o preenchimento do conhecimento inerente as lacunas da graduação, promove satisfação pessoal e valorização profissional, visto que a graduação não atende às demandas e requisitos do mercado de trabalho.

Durso et al. (2016) apontam que a inserção no mercado de trabalho é um dos elementos que fomenta a autodeterminação dos alunos para cursar mestrado acadêmico. Sendo que aqueles que tiveram contato com a pesquisa científica, por meio da iniciação científica, possuem maior prospecção para o ingresso no mestrado. A partir da Teoria do Capital Humano e da Teoria da Autodeterminação, bem como da observação dos aspectos relatados nos estudos empíricos, delineou-se os procedimentos metodológicos da pesquisa.

\section{Delineamento e Procedimentos Metodológicos}

A aplicação do instrumento de coleta de dados compreendeu os acadêmicos que ingressaram 
em um Programa de Pós-Graduação em Contabilidade nos anos de 2015 e 2016. Totalizaram-se 35 potenciais participantes, sendo que foram enviados convites para 19 mestrandos selecionados de modo não probabilístico com vistas a miscigenação dos participantes, sendo que 12 mestrandos efetivamente aceitaram participar das entrevistas. A escolha do programa foi direcionada pela acessibilidade aos participantes e pelo curso possuir mais de 10 anos de atividade.

Para a coleta de dados foi utilizada a técnica de entrevista com roteiro semiestruturado que foi elaborado a partir dos estudos de Avelino, Cunha e Nascimento (2013), Barth (2015), Barth, Ensslin e Borgert (2016) e Durso et al. (2016). Destaca-se que a opção por utilizar majoritariamente estudos nacionais é justificada pela semelhança dos contextos vividos pelos respondentes, pois conforme citado por Sampieri, Collado e Lucio (2013) os resultados de estudos estrangeiros são sustentados por outra realidade em virtude das diferenças estruturais e culturais, podendo enviesar as triangulações e a sustentação teórica da pesquisa.

As entrevistas são classificadas como semiestruturada, pois apesar de possuírem roteiro prédefinido, os entrevistadores tinham a liberdade de acrescentar outros questionamentos no decorrer das conversas (MARTINS; THEÓPHILO, 2009). O roteiro foi composto por tópicos relacionados as alterações sociais, financeiras e psicológicas ocorridas na vida dos mestrandos ao comparar o antes e o depois do ingresso no programa e aspectos motivacionais que influenciaram a decisão por cursar o mestrado em contabilidade. Nesse sentido, buscou-se dar voz aos participantes e entender sua percepção perante esse processo. O Quadro 2 apresenta de maneira sucinta o roteiro utilizado nas entrevistas.

\section{Quadro 2 - Roteiro de entrevistas}

\begin{tabular}{|c|c|c|c|}
\hline \multicolumn{2}{|c|}{$\begin{array}{c}\text { Alterações se comparado o antes e após o ingresso } \\
\text { no mestrado - (Bloco 1) }\end{array}$} & \multirow{2}{*}{\multicolumn{2}{|c|}{$\begin{array}{l}\text { Fatores Motivacionais para Cursar o Mestrado - } \\
\text { (Bloco 2) }\end{array}$}} \\
\hline $\begin{array}{c}\text { Sociais (Tempo } \\
\text { dedicado) }\end{array}$ & Financeiras (Gastos) & & \\
\hline Família & Lazer & \multirow{4}{*}{ 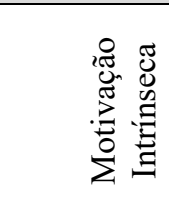 } & Satisfação pessoal \\
\hline Lazer & Atividades Esportivas & & Efetividade \\
\hline Atividades Esportivas & Aperfeiçoamento Profissional & & Autonomia \\
\hline $\begin{array}{l}\text { Aperfeiçoamento } \\
\text { Profissional }\end{array}$ & Encontro colegas e amigos & & Aumento do Conhecimento \\
\hline $\begin{array}{l}\text { Encontro colegas e } \\
\text { amigos }\end{array}$ & Materiais intelectuais & \multirow{4}{*}{ 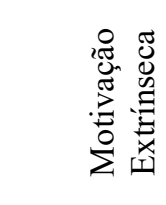 } & Imposição \\
\hline Leituras & Vestuário/Transporte/Moradia & & Ego/Autoestima/Status \\
\hline Sono & Alimentação & & Recompensa (Remuneração) \\
\hline \multirow{2}{*}{$\begin{array}{l}\text { Outras categorias não } \\
\text { abordadas no roteiro. }\end{array}$} & \multirow{2}{*}{$\begin{array}{l}\text { Outras categorias não } \\
\text { abordadas no roteiro. }\end{array}$} & & Crescimento Profissional \\
\hline & & \multirow{2}{*}{\multicolumn{2}{|c|}{$\begin{array}{l}\text { Outros fatores motivacionais } \\
\text { E se você pudesse voltar no tempo, teria ingressado } \\
\text { no mestrado? }\end{array}$}} \\
\hline \multirow{2}{*}{\multicolumn{2}{|c|}{$\begin{array}{l}\text { Você acredita que essas mudanças em relação ao } \\
\text { tempo e gastos econômicos afetaram te afetaram } \\
\text { psicologicamente? }\end{array}$}} & & \\
\hline & & \multicolumn{2}{|c|}{$\begin{array}{c}\text { Se arrepende de algo referente ao seu planejamento } \\
\text { ou a sua trajetória do mestrado? Faria algo } \\
\text { diferente? }\end{array}$} \\
\hline
\end{tabular}

Fonte: Elaborado pelos autores com base em Avelino, Cunha e Nascimento (2013), Barth (2015), Barth, Ensslin e Borgert (2016) e Durso et al. (2016).

As variáveis motivacionais que compõem o tópico do Bloco 2 foram definidas a partir da identificação das mais preponderantes em estudos anteriores. Cabe destacar, que os fatores não foram tratados de modo excludentes, nem se restringiram aos pré-definidos pelos pesquisadores. Assim, os entrevistados tinham a liberdade de citar outros aspectos que pudessem ter influenciado o ingresso no mestrado. Optou-se primeiro por abordar as modificações ocorridas na vida dos mestrandos e posteriormente os fatores motivacionais, para que assim fosse fomentado o diálogo e o clima amistoso entre os entrevistadores e os participantes. Sendo que os diálogos das modificações possibilitaram que as respostas sobre alterações psicológicas e arrependimentos fossem efetuadas de modo detalhado pelos mestrandos.

Além da entrevista, foi aplicado um questionário que objetivava a caracterização da amostra e captação de algumas informações de cunho pessoal e profissional. As premissas para a validação dos instrumentos de coleta de dados seguiram as recomendações de Martins e Theóphilo (2009), sendo 
efetuadas as seguintes validações: (i) validade de conteúdo; (ii) validade aparente; e (iii) pré-teste, no qual algumas perguntas foram modificadas após sugestões, visando melhorar a compreensão dos questionamentos, bem como a postura dos entrevistadores.

Quanto aos aspectos éticos e formais, em todas as conversas o mesmo pesquisador abordou os mesmos tópicos, a fim de padronizar o escopo da entrevista. Os participantes assinaram um termo de livre consentimento em que permitiam a gravação de áudio, e os pesquisadores forneceram um protocolo ético assinado, no qual assumiram o compromisso de somente utilizar as informações para fins científicos, sem expor os dados pessoais dos respondentes.

Ao final das entrevistas todas as conversas foram transcritas e enviadas por e-mail aos entrevistados, informando-os que possuíam três dias úteis para modificar alguma resposta que pudessem constrangê-los e reenviar o novo documento aos pesquisadores. As 12 entrevistas totalizaram cinco horas e trinta e um minutos de duração, sendo empregado aproximadamente trinta e quatro horas para a transcrição das mesmas. Todas as entrevistas foram agendadas antecipadamente e foram realizadas pessoalmente ou via conferência de vídeo, sendo prezado o contato visual com cada participante a fim de observar suas reações e estabelecer confiança com os pesquisadores.

Além das falas individuais utilizou-se da Análise de Discurso do Sujeito Coletivo para identificar as representações sociais dos indivíduos. A partir das expressões-chave e do agrupamento das ideias principais de cada relato é construído um discurso em primeira pessoa que representa a coletividade na fala de um único indivíduo (LEFEVRE; LEFEVRE, 2014).

\section{Análise de Discussão dos Resultados}

A partir do compromisso de manter o anonimato firmado junto aos participantes das entrevistas, optou-se por não realizar a caracterização detalhada da amostra. Na Tabela 1 é apresentado um breve perfil dos respondentes.

Tabela 1 - Perfil dos Respondentes

\begin{tabular}{|c|c|c|c|c|c|c|c|}
\hline \multicolumn{2}{|c|}{ Gênero } & \multicolumn{2}{|c|}{$\begin{array}{l}\text { Bolsista } \\
\text { CAPES? }\end{array}$} & \multicolumn{2}{|c|}{$\begin{array}{l}\text { Morava em outra cidade } \\
\text { antes do ingresso no } \\
\text { mestrado? }\end{array}$} & \multicolumn{2}{|c|}{$\begin{array}{c}\text { Possuía vínculo empregatício } \\
\text { antes do mestrado? }\end{array}$} \\
\hline Feminino & Masculino & Sim & Não & Sim & Não & Sim & Não \\
\hline 07 & 05 & 11 & 01 & 08 & 04 & 10 & 02 \\
\hline \multirow{2}{*}{$\begin{array}{l}\text { Média de } \\
\text { Idade }\end{array}$} & \multicolumn{4}{|c|}{ Antes do mestrado atuava como docente? } & \multicolumn{3}{|c|}{ Atualmente possui vínculo empregatício? } \\
\hline & \multicolumn{3}{|c|}{ Sim } & \multicolumn{2}{|l|}{ Não } & Sim & Não \\
\hline \multicolumn{2}{|c|}{31 anos* } & \multicolumn{2}{|c|}{04} & 08 & \multicolumn{2}{|c|}{04} & 08 \\
\hline
\end{tabular}

*Desvio padrão 8,94 .

Fonte: Dados da Pesquisa.

Os respondentes da pesquisa de Barth (2015) possuíam média de 34 anos com desvio padrão de 5,47 anos, frente a 31 anos e desvio padrão aproximado de 8,94 anos desta pesquisa. No estudo de Barth (2015), 41,30\% dos participantes atuavam como docentes antes ou durante o mestrado, frente a 33,33\% da amostra componente desta investigação. Notam-se similaridades entre os participantes de ambas investigações, podendo ser indícios de padronização do perfil dos pós-graduandos em contabilidade participantes de ambas as pesquisas.

\subsection{Alterações Relacionadas ao Tempo Dedicado aos Aspectos Sociais}

Para Borges, Faria e Gil (2007) o compromisso e disposição para a pesquisa são fatores essenciais para o sucesso de um mestrando, sendo que tais atividades demandam dedicação e tempo por parte do aluno. Na Tabela 2 são expostas as modificações em relação ao tempo dedicado para cada item social abordado nas entrevistas e a segregação das respostas positivas de acordo com a intensidade de tempo, ou seja, menos ou mais tempo dedicado a cada aspecto. 
Tabela 2 - Modificações no tempo dedicado as categorias sociais

\begin{tabular}{|c|c|c|c|c|}
\hline \multirow{2}{*}{ Aspectos Sociais } & \multirow{2}{*}{ Sim } & \multicolumn{2}{|c|}{ Intensidade } & \multirow{2}{*}{ Não } \\
\hline & & Menos (-) & Mais (+) & \\
\hline Tempo dedicado a família, presencialmente ou não. & 10 & 09 & 01 & 02 \\
\hline Tempo dedicado a Lazer. & 10 & 08 & 02 & 02 \\
\hline Tempo dedicado a Atividades Esportivas. & 09 & 07 & 02 & 03 \\
\hline Tempo dedicado a Aperfeiçoamento Profissional. & 10 & 08 & 02 & 02 \\
\hline Tempo dedicado a Encontro com Colegas e Amigos. & 10 & 09 & 01 & 02 \\
\hline Tempo dedicado a Leituras. & 12 & 10 & 02 & - \\
\hline Tempo dedicado ao Sono. & 11 & 10 & 01 & 01 \\
\hline
\end{tabular}

Fonte: Elaborado pelos autores.

A maioria dos participantes indicaram que houve modificação no tempo dedicado a todas as categorias sociais. No Erro! Fonte de referência não encontrada. são apresentados os discursos do sujeito coletivo construídos e que retratam a percepção de tais modificações.

Erro! Fonte de referência não encontrada. - Discursos do sujeito coletivo

\begin{tabular}{|c|c|c|c|}
\hline 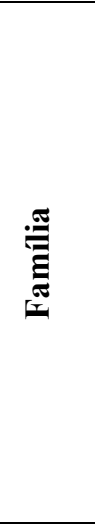 & $\begin{array}{l}\text { O tempo de dedicação à minha família } \\
\text { diminuiu durante o mestrado, } \\
\text { principalmente devido a carga de leitura e } \\
\text { demais atividades exigidas pelas } \\
\text { disciplinas. No entanto, nem por isso perdi } \\
\text { o contato familiar. Sempre busquei uma } \\
\text { forma de estar em contato com a minha } \\
\text { família, problema é que em épocas de } \\
\text { seminário, dead line e dissertação este } \\
\text { contato torna-se reduzido. }\end{array}$ & 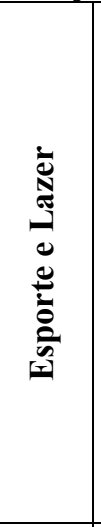 & $\begin{array}{l}\text { Discurso 1: No mestrado não tem muito } \\
\text { tempo para lazer e esporte. Há uma carga } \\
\text { de trabalho e leituras intensas, então nos } \\
\text { raros momentos que me dedico a essas } \\
\text { atividades fico me sentindo culpado por } \\
\text { não estar me dedicando ao mestrado. } \\
\text { Discurso 2: Melhorou, pois antes eu } \\
\text { trabalhava muito. Normalmente, } \\
\text { trabalhava de dia e lecionava à noite, então } \\
\text { no mestrado consegui conciliar melhor. } \\
\text { Além disso, praticar esportes é importante } \\
\text { para manter a sanidade mental. }\end{array}$ \\
\hline 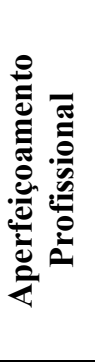 & $\begin{array}{l}\text { Eu não tenho mais tempo de me dedicar a } \\
\text { outras atividades que não sejam } \\
\text { relacionadas com o mestrado. Muitos dos } \\
\text { cursos e treinamentos que iniciei acabei } \\
\text { deixando em função do pouco tempo que eu } \\
\text { tenho disponível, pois quando não estou } \\
\text { enrolado com artigos de disciplinas ou com } \\
\text { a dissertação, estou tendo alguma crise } \\
\text { existencial. }\end{array}$ & 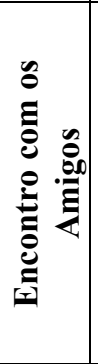 & $\begin{array}{l}\text { O encontro com meus amigos diminuiu } \\
\text { muito depois que entrei no mestrado, hoje } \\
\text { eu não saio muito com eles. Além disso, } \\
\text { meu círculo de amizade mudou bastante, } \\
\text { perdi ou me distanciei de muitos amigos, } \\
\text { hoje basicamente convivo com o pessoal do } \\
\text { mestrado. }\end{array}$ \\
\hline 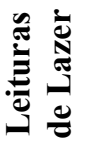 & \multicolumn{3}{|c|}{$\begin{array}{l}\text { Comecei a ler mais após o ingresso no mestrado, no entrando eu reduzi bastante as leituras que } \\
\text { não tinham relação com as exigidas pelas disciplinas. Isso foi tanto pela falta de tempo, como } \\
\text { pelo sentimento de culpa por não estar lendo algo relacionado as disciplinas. }\end{array}$} \\
\hline
\end{tabular}

Fonte: Dados da pesquisa.

Apesar de na coletividade o convívio familiar ter sido diminuído, Arthur expôs que houve aumento do contato familiar, motivado pela tensão e preocupações com as demandas do mestrado. Esse estreitamento no relacionamento pode ser atribuído a busca por apoio psicológico para superar os desafios vivenciados no stricto sensu. Os relatos em geral estão em linha com os achados de Barth (2015) que verificou alterações negativas no convívio familiar após o ingresso no mestrado.

Em sua maioria, o engajamento em atividades esportivas e de lazer foi afetado. Entretanto, Davi e Valentina citam que houve aumento no tempo dedicado a essas classes. As respostas desses mestrandos indicam que essa alteração positiva se deve ao fato da diminuição da carga horária de trabalho que havia quando exerciam suas atividades profissionais.

Os participantes que alegaram alterações negativas em tais categorias, expõem que o curso exige dedicação e isso acaba consumindo tempo o "[...] mestrado não é uma coisa fácil, você tem que estudar 
muito, você tem que aprender a pensar" (Alice). Nessa mesma ótica Manuela afirma que antes de ingressar no mestrado "[...] tinha outro horário, outra vida", sendo que questões psicológicas motivaram a diminuição do lazer, pois "eu não me permitia sair, porque uma ou outra vez eu ia em um parque e eu ficava pensando no que tinha acumulado e eu me sentia muito culpada" (Manuela).

As atividades esportivas mostram-se relevantes para a "[...] mente ficar funcionando também" (Arthur). Borges, Faria e Gil (2007) citam a importância de mesclar o tempo dedicado aos compromissos acadêmicos com as atividades pessoais, para que o aluno não se sinta desmotivado, pois este é um dos principais fatores da evasão acadêmica. Os achados de Barth (2015) indicam que os pós-graduandos acabam diminuindo o tempo dedicado as atividades pessoais, em face ao mestrado. Torna-se relevante incentivar e conscientizar os discentes a se engajarem em atividades esportivas e de lazer, à medida que o ambiente do stricto sensu é estressante (Rezende, Miranda, Pereira \& Cornacchione, 2017), fato que pode comprometer o desempenho acadêmico.

Quanto ao aperfeiçoamento profissional, dois participantes destacaram que não houve alteração relacionada a dedicação, na mesma proporção, outros dois afirmam que o envolvimento com tais tarefas aumentou após o ingresso no programa. Para aqueles que diminuíram, mas ainda continuam participando de atividades para aperfeiçoamento profissional, destaca-se a atenção atribuída a cursos de inglês, conforme falas apresentadas no Quadro 3.

\section{Quadro 3 - Atenção atribuída ao inglês}

Alice: [...] quando eu entrei no mestrado, eu senti mais necessidade ainda de aprender inglês.

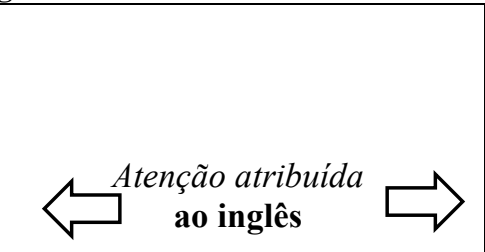

ao inglês
Isabella: Antes eu fazia curso de inglês, tanto particular, lá na própria instituição que eu estudava, como o fornecido pelo governo. [...] Agora eu faço particular via Skype ${ }^{\circledR}$, para não ter também a perda de tempo para sair de casa e me deslocar até uma escola de inglês.

Fonte: Dados da pesquisa.

Essa atenção pode ser justificada por alguns enfoques percebidos nas falas dos participantes. O primeiro é o domínio de uma língua estrangeira para facilitar o desempenho das atividades de pesquisas, conforme destacado pelo Miguel, "na minha dissertação eu não tenho literatura em português, nenhuma! Todas são em inglês [...]". O segundo fator, são as pressões, exigências e obrigações em relação a dominar outro idioma, pois como observado pelo Arthur "[...] é uma ordem social realmente, fazer mestrado, fazer doutorado, ter curso de idioma, ter proficiência”, e também, é uma exigência dos programas de pós-graduação. Por fim, alguns participantes admitem que a necessidade de dominar outro idioma, principalmente o inglês, está relacionado com o fato de ser um dos itens avaliados de maneira direta ou indireta na seleção de alunos para o doutorado nos diversos programas de pós-graduação do Brasil. Ainda referente à capacitação profissional, Arthur afirma que há cursos de extensão oferecidos pelas instituições, contudo eles são pouco procurados pelos alunos de programas de pós-graduação "também - há - aqui esses cursos de extensão [..] mas, por incrível que pareça pouca gente adere [...]".

Essa baixa aderência pode ser justificada pelas falas da Isabella "[...] a partir do momento que eu entrei no mestrado eu não consegui fazer mais esse (curso de inglês) do governo em função do tempo, embora gratuito [...]" e da Laura quando expõe que tentava cursar as aulas de inglês ofertadas pela instituição, contudo devido aos compromissos do mestrado precisava interrompê-las "[...] eu fiz vários, eu comecei fazendo, não terminei quase nenhum. Eu começava, eu tentava. Todo o início de semestre eu ia fazer o curso de inglês, quando chegava mais próximo dos meus seminários eu não conseguia acompanhar".

Em relação a convivência e o tempo dedicado ao encontro com os amigos, 10 alunos afirmaram que essa categoria teve o tempo modificado, sendo que 09 afirmam que houve diminuição do tempo. Quando questionados se o círculo de amizades foi modificado e se ainda mantinham contato com os amigos de antes do mestrado, alguns citaram que perderam essa ligação ou que os amigos mudaram. 
Em termos de relacionamentos, Arthur e Davi destacaram a importância de ter parceiros (as) afetivos (as) que saibam lidar com as exigências e consequentemente as ausências que o mestrado impõe. Para que o relacionamento não seja interrompido durante o mestrado o parceiro (a) necessita ser compreensivo, leal e ter maturidade para lidar com a situação. Conforme, exposto no Quadro 4:

\section{Quadro 4 - Relacionamentos afetivos}

\section{Arthur: [...] o relacionamento também} é muito interferido nisso aqui tudo. Então, é realmente um pacto com quem você está. É puxado, é sofrido e a pessoa tem que entender, tem que ter maturidade para isso também.

Fonte: Dados da pesquisa.

Em relação as leituras de lazer, todos citaram que houve alteração no volume lido. Sendo que esse tipo de leitura diminuiu após o ingresso no programa para 10 alunos, e para 02 aumentaram. Para Borges, Faria e Gil (2007) o professor deve possuir uma série de habilidades que podem ser aprimoradas ou desenvolvidas, dentre outras formas, por leituras aplicadas. Nesse contexto, as disciplinas do curso de mestrado possuem elevada carga de leitura. Os mestrandos precisam ler para realizar trabalhos de pesquisas e posteriormente elaborarem artigos. Para Sophia, Miguel, Arthur e Bernardo a falta de tempo impede a realização de leituras que não sejam as ligadas ao mestrado. Isabella cita que esse tipo de leitura já não é mais uma forma de lazer, pois "[...] eu já passei lendo o dia inteiro, então aquilo para mim não é um descanso. [...] eu não consigo ler, porque eu acho que isso já é rotina do dia”.

Quando questionados se o tempo dedicado ao sono sofreu alterações, nota-se alguns aspectos interessantes. Davi cita que não houve alterações, Valentina expõe que melhorou, principalmente no segundo ano do mestrado. Observa-se que majoritariamente o primeiro ano do mestrado é o qual temse mais modificações referentes a rotina de sono. Conforme citado pela Manuela, o primeiro ano é o período que se tem mais obrigações e consequentemente maior volume de tarefas. A rotina de sono não possui um padrão e depende de algumas circunstâncias em andamento e relacionadas as atividades do mestrado, como o período de elaboração e apresentação de seminários (Laura), aulas no período da manhã do dia seguinte (Sophia, Laura, Bernardo, Valentina e Manuela), elaboração de artigos (Helena) e escrita do trabalho de dissertação (Isabella).

Os entrevistados foram questionados se em alguma outra categoria houve modificação no tempo dedicado e que não tivesse sido abordada nos tópicos da entrevista. Diante disso, Sophia e Manuela citaram que o tempo dedicado a tocar instrumentos musicais foi impactado, sendo que para Manuela essa atividade era parte do seu lazer e para Sophia a "[...] música é uma coisa que me faz muita falta, e eu não tenho mais aquele contato que eu gostaria".

Ao analisar os relatos dos participantes, percebe-se que além dos fatores já citados, o choque com a nova realidade e a falta de organização, cronograma ou planejamento das tarefas diárias são outros motivos indicados como causas para as modificações nas categorias estudas, pois "o mestrado foi uma coisa muito nova. [...] é uma mudança muito drástica" (Alice). No

Quadro 5 é retratado o discurso coletivo sobre a dificuldade para adaptação as mudanças na rotina após o ingresso no mestrado.

\section{Quadro 5 - Percepção dos fatores de modificação na vida dos estudantes}

O mestrado é muito diferente da graduação, o primeiro ano é muito impactante. Dormir de madrugada, acordar cedo, administrar inúmeras obrigações, isso é bem penoso.

Fonte: Dados da pesquisa.

Diante dessa nova realidade do ingresso no curso, das modificações e da percepção do novo, Arthur afirma que o mestrado evidencia "toda uma lógica diferente de... você é mais livre com os seus horários, e... consequentemente tem que ter mais responsabilidade pelas suas ações também né". Para 
Manuela "[...] você não sabe o que faz primeiro, acho que uma organização poderia ter ajudado nesta rotina". Percebe-se que o mestrado "impacta" a realidade do mestrando, sendo que o planejamento do tempo poderia auxiliar a lidar com a rotina de estudos e tarefas do aluno. As trocas de experiências entre os alunos de outros períodos ou o auxílio da coordenação pode proporcionar aos ingressantes noções para o planejamento de sua rotina diária e consequentemente, minimizar os impactados ocasionados pelo ingresso no programa.

Percebe-se que é ilusório tentar separar a vida pessoal da acadêmica. Normalmente, o mestrando tende a afastar-se dos compromissos familiares, pessoais ou sociais em face das tarefas do programa. Contudo, é importante que o convívio social não seja afetado de modo elevado, visto que isso interfere na motivação pessoal, qualidade de vida e equilíbrio emocional, podendo comprometer o desempenho acadêmico do aluno (BORGES; FARIA; GIL, 2007).

\subsection{Alterações Relacionadas as Modificações Financeiras}

Quando questionados se o padrão de vida foi mantido após o ingresso no mestrado a maioria dos entrevistados afirmaram que ocorreram mudanças significativas, principalmente nos aspectos financeiros. Dos 12 mestrandos entrevistados, 9 são bolsistas e não possuem vínculo empregatício. Somada a essa evidência há a alta carga de tempo destinada as tarefas do programa, que pode indicar ausência de vínculo empregatício e dependência da bolsa de estudos, visto que somente um participante da pesquisa não é bolsista CAPES. Na

Figura 2 há o comparativo da renda dos alunos em salários mínimos antes e após o ingresso no programa de mestrado.

Figura 2. Comparativo das rendas em salários mínimos.

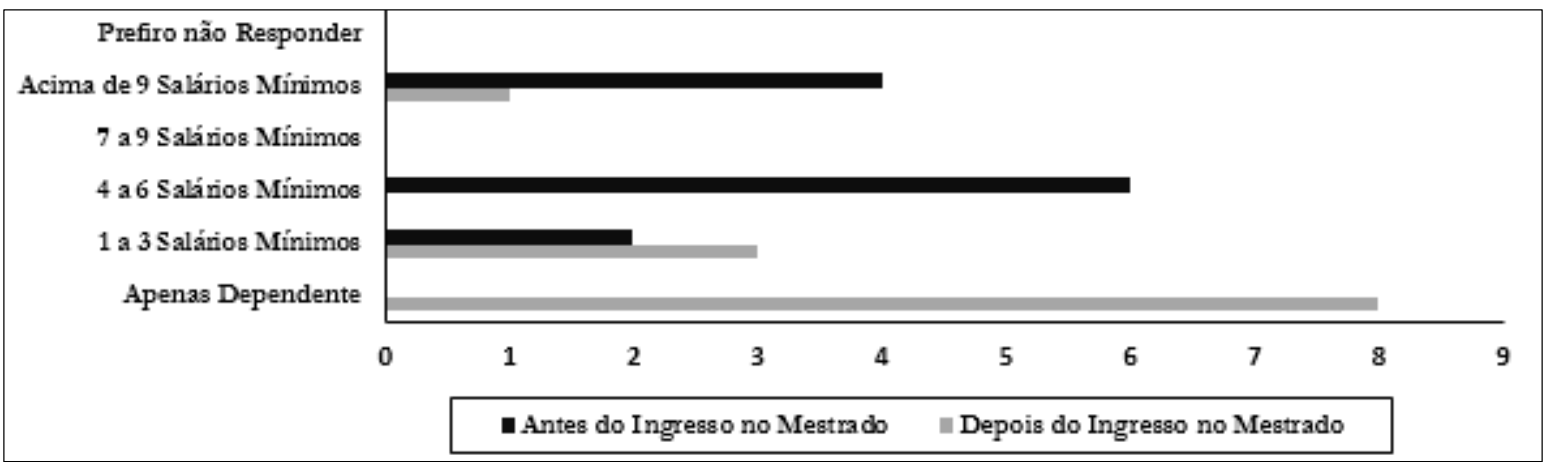

Fonte: Dados da pesquisa.

A partir das modificações verificadas foram construídos os Discursos Coletivos expostos no

Quadro 6. Os relatos denotam que o padrão de vida dos discentes foi alterado consideravelmente. A influência financeira nas práticas esportivas foi confirmada pela maioria dos discentes. No entanto, foram destacados outros aspectos como a própria questão do tempo, impossibilitando a continuidade da prática de atividades esportivas. Por exemplo, Helena enfatizou que "[...] não quis pagar academia nem nada. Poderia ter feito corrida, ou algo assim, como eu sempre estava cansada, não se forçava". Referente aos gastos com aperfeiçoamento profissional ou pessoal o aspecto financeiro foi preponderante nas decisões. Mesmo conscientes da necessidade do aperfeiçoamento profissional e do domínio de outros idiomas, o ritmo acadêmico e a restrição financeira foram fatores limitantes das possibilidades dos mestrandos em realizar outros cursos de capacitação. Além disso, os encontros com colegas e amigos em alguns casos foi modificado devida a redução dos recursos financeiros, fazendo com que houvesse a busca por outros meios menos dispendiosos para socializar e conversar.

Referente aos materiais intelectuais, os participantes relataram que os gastos nessa categoria 
foram restritos. À exemplo, Laura enfatizou que a aquisição de materiais intelectuais acontecia apenas quando sobrava alguma quantia que poderia ser investida em literatura que não fosse direcionada ou exigida pelo mestrado. Outra categoria que foi afetada foi o vestuário. Os discentes reduziram o consumo e priorizaram questões de maior necessidade como exposto por Miguel "[...] e isso é uma das coisas também que gente vai deixando [...], uma hora quando der a gente compra, porque ainda tem a roupa, mas uma hora acaba e daí você precisa ir lá e comprar um tanto. Então roupa, vestuário em geral é uma coisa que a gente fica... se depender da bolsa a gente não compra, não compra mesmo". Arthur sintetiza essas alterações da seguinte forma: "[...] você reformula seus hábitos de consumo realmente, do que realmente você precisa ou não, então faz. Desde que eu entrei nesse mestrado acho que eu comprei uma ou duas roupas".

\begin{tabular}{|c|c|c|c|}
\hline 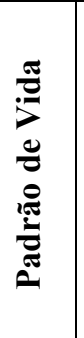 & $\begin{array}{l}\text { Meu padrão de vida foi alterado de forma negativa } \\
\text { depois que ingressei no mestrado, tive que me } \\
\text { adequar a bolsa da CAPES que ganhava no valor } \\
\text { de } \mathrm{R} \$ 1.500 \text {. De certa forma, a questão financeira } \\
\text { é um fator que me preocupou e me desgastou muito } \\
\text { durante a pós-graduação. }\end{array}$ & 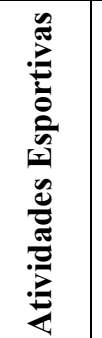 & $\begin{array}{l}\text { Devido a questão financeira e até pelo } \\
\text { próprio tempo, eu tive que reduzir as } \\
\text { atividades esportivas durante o mestrado. } \\
\text { No entanto, sei da importância que essas } \\
\text { atividades desempenham na disposição } \\
\text { física e mental da pessoa. }\end{array}$ \\
\hline 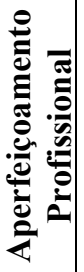 & $\begin{array}{l}\text { O fator financeiro e o tempo acabaram } \\
\text { influenciando na decisão de não fazer cursos de } \\
\text { aperfeiçoamento durante o mestrado. Se for ver, } \\
\text { um curso básico de inglês custa no mínimo uns } \\
20 \% \text { da bolsa. }\end{array}$ & 焉 & $\begin{array}{l}\text { Eu reduzi a compra de livros, no mestrado } \\
\text { dei prioridade em adquirir materiais mais } \\
\text { específicos, e eu também procurava outros } \\
\text { meios de acesso dos conteúdos vistos em } \\
\text { sala. }\end{array}$ \\
\hline : & $\begin{array}{l}\text { O aspecto financeiro não afetou muito a questão da } \\
\text { alimentação, porque com o Restaurante } \\
\text { Universitário (RU) tem como ter uma boa } \\
\text { alimentação e uma folga no orçamento. }\end{array}$ & 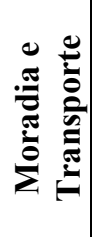 & $\begin{array}{l}\text { Por causa do mestrado eu procurei algum } \\
\text { lugar próximo da instituição para evitar } \\
\text { gastar com transporte e tempo com } \\
\text { deslocamento. Sempre procurando um } \\
\text { custo-benefício que se adaptasse ao meu } \\
\text { orçamento. }\end{array}$ \\
\hline
\end{tabular}

Fonte: Dados da pesquisa.

As falas dos entrevistados permitem refletir sobre as prioridades dos mestrandos, que em face das despesas com aluguel, alimentação e lazer, o vestuário passa a ter relevância secundária sendo adquirido de acordo com a necessidade de compra ou disponibilidade financeira. Nesse sentido, "[...] sair, comprar uma roupa nova, isso já não deu no mestrado" (Laura).

Questionados sobre o efeito das finanças na alimentação a maioria dos entrevistados direcionaram ênfase a importância do Restaurante Universitário (RU), sendo um aliado nas refeições durante o mestrado, pois o mesmo oferece uma alimentação balanceada, de qualidade e com valores acessíveis. Tais discussões vão ao encontro da rotina do próprio mestrando na universidade, como o RU funciona nos três turnos, facilita o dia a dia dos estudantes que estão dedicados integralmente nos laboratórios de pesquisa, como observado por Laura. Sobre a moradia durante o período do mestrado, os entrevistados preferiram residir em lugares mais acessíveis devida à limitação financeira. Laura expõe que procurou "[...] um lugar mais barato também por essa questão financeira". Já Isabella destaca que "[...] quando eu mudei de cidade encontrei um apartamento com preço razoável perto de outros, mas, foi o que eu encontrei na época. Após um ano, encontrei um mais barato, optei por mudar porque a bolsa não era suficiente e eu precisava da ajuda dos meus pais, então isso acaba influenciando sim na questão da moradia".

O valor da bolsa, aquém das necessidades dos mestrandos, e que impacta principalmente aqueles que vieram outras localidades e que por vezes os pais não podem ajudar no pagamento das despesas. 
Nesse sentido, Miguel salienta que "[...] nem todo mundo tem pai e mãe atrás que consegue mandar dinheiro, eu não tenho isso. Assim, às vezes que eu precisei muito, muito, muito, eu pedi, minha mãe se desdobrou e mandou $R \$ 150$. Então assim, é complicado porque a gente não tem com quem contar para isso". Nesta mesma linha Laura enfatiza que "[...]é muito pouco, (a bolsa) é um absurdo de pouco, não cobre todos os gastos, é um kit sobrevivência. Chega uma hora que você nem pensa o que você pode e o que você não pode, só analisa a situação e diz "não, o mestrado são dois anos".

Além das dificuldades financeiras, a insegurança quanto ao futuro desperta sentimentos de dúvidas e inseguranças nos discentes. Helena discorre sobre as inquietações pessoais e preocupações com o futuro profissional e com a escolha de cursar o mestrado "[...] eu tinha um bom salário antes, uns três, quatro salários mínimos, eu decidi isso [...]. Antes, eu tinha tudo na mão, tudo fácil sabe? Eu vejo agora como era fácil a minha vida, e ai fui ser bolsista, fui gastar tudo o que eu tinha economizado. E às vezes... até hoje eu me pego pensando se eu realmente fiz uma escolha certa, sabe? Que eu tinha um bom cargo, tinha um padrão muito melhor, e agora eu continuo desempregada”.

A diminuição da renda é vista como um fator impactante na vida dos estudantes, modificando o padrão de vida e sendo um dos elementos primordiais a ser observado para a continuidade no mestrado. Assim, enfatiza-se a necessidade de planejamento financeiro antecipado, auxílio de fontes externas e readaptação orçamentária para atingir seu objetivo no programa. As evidências coadunam com as observações de Borges, Farias e Gil (2007) que apontam os aspectos financeiros como um fator essencial para o sucesso dos mestrandos na conclusão do curso. Ademais, as falas alinham-se aos achados de Barth (2015) que verificou a influência de elementos financeiros na evasão dos mestrandos do programa analisado. Percebe-se que o mestrado exige deciões estratégicas, programação financeira e deve ser planejado a fim de ser viabilizado (BORGES; FARIA; GIL, 2007), pois nem sempre o grau de mestre maximizará a remuneração. Barth (2015) observou que para 56,52\% dos participantes de sua pesquisa, o título de mestre não maximizou os retornos financeiros.

\subsection{Modificações Psicológicas Auto Atribuídas ao Mestrado}

Após serem questionados sobre as alterações sociais e financeiras ocorridas devido ao ingresso no mestrado, questionou-se os alunos se em algum momento essas modificações os impactaram psicologicamente. Os comentários dos que reconheceram alguma mudança no comportamento devido ao mestrado foram submetidos à análise de frequência de palavras e a partir disso foi elaborada a nuvem de palavras exposta na Figura 3.

Figura 3. Frequência de palavras - Alterações psicológicas

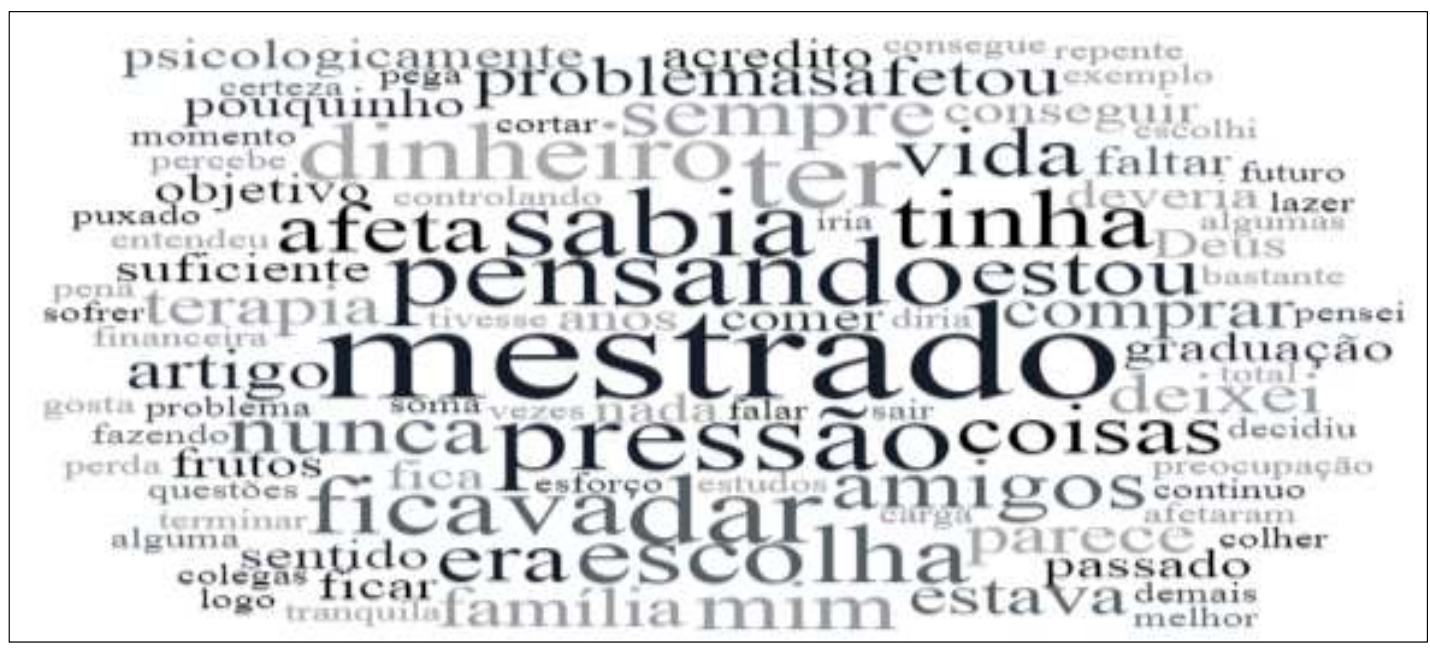

Fonte: Dados da pesquisa. 
Nota-se que as palavras mais frequentes nas falas dos discentes são relacionadas ao ambiente do mestrado (e. g. pressão), aos aspectos financeiros (e. g. escolha, comprar, dinheiro) e as reflexões sobre as modificações ocorridas após o ingresso no mestrado se comparado a rotina anterior (e. g. pensando, sabia, tinha). Diante disso, no Quadro 7 é apresentado o Discurso Coletivo que representa as alterações psicológicas advindas dessas modificações.

\section{Quadro 7 - Discurso Coletivo Inerente as Alterações psicológicas}

Me afetou psicologicamente, porque a carga de estudos é elevada e nada na vida te prepara para isso. Lidar com ansiedade, problemas financeiros, a pressão para publicações, tudo isso impacta. Teve um período que desembolsei dinheiro com terapia. Mas a questão financeira é o principal problema, quando chega o fim do mês tem que ficar controlando, manobrando para conseguir se manter e não faltar nada.

Fonte: Dados da pesquisa.

As modificações psicológicas apontadas pelos mestrandos advêm das pressões pelo desempenho, da dúvida quanto à capacidade humana em realizar as tarefas, limitação financeira e da insegurança em relação ao futuro. Sendo que reflexões acerca da decisão de ingressar no mestrado são frequentes, bem como o sentimento de escolha pessoal, de que estar no mestrado não foi uma decisão forçada, conforme exposto no Quadro 8.

\section{Quadro 8 - Reflexões}

Helena: [...]. você ficar comparando a vida que você tinha antes, e a que decidiu levar agora, eu demorei um ano e pouquinho para entender: "você que decidiu isso, não fique pensando, se apegando no passado, no que você deixou. Ah deixei minha família, deixei meus amigos, deixei meu conforto, deixei meu dinheiro, que eu ganhava e que era bom, meu trabalho que não era tão puxado, [...] ganhando um alto salário". Então assim, é uma coisa que pega bastante, sabe? Que parecia que não ia ter fim, você estudava, você se dedicava, parece que nunca é o suficiente. [...] sempre queriam mais de você, que você desse mais, parece que todo o seu esforço, o seu melhor, você achando que deu o seu melhor parece que nunca é o suficiente. Então é bem complicado, essa questão psicológica pega muito, tanto de tempo como financeiro. E essa comparação de você pensar no seu futuro, será que realmente vai valer a pena? Sabe uma coisa que eu ficava pensando? Não é um pensamento suicida, nada disso, mas eu ficava pensando "gente, tomara que no futuro, eu consiga colher os frutos disso. Que isso tenha valido a pena"

Fonte: Dados da pesquisa.

Além de Lorenzo, a mestranda Laura afirma que a noção de que o ingresso no mestrado foi uma escolha pessoal, que não foi algo imposto, ajuda a minimizar o sentimento de arrependimento ou mesmo para servir de conforto em momentos turbulentos (Quadro 9).

Quadro 9 - Reflexões (2)

Laura: [...] eu que escolhi estar no mestrado, eu que escolhi participar do processo, então eu fiz as escolhas, isso ameniza um pouco desse impacto sabe? Saber que você escolheu estar aí. Eu toda a vez que me sentia triste, desgastada, porque a gente fica frustrado, eu sabia que eu tinha feito a opção.

Fonte: Dados da pesquisa.

Da mesma forma, Davi argumenta que "a gente (pós-graduandos) leva e vai levando, porque a gente (pós-graduandos) tomou essa decisão. [...]”. Essas percepções justificam o fato de a frequência de palavras indicar a alta utilização de verbos no pretérito, pois os participantes citam as reflexões que realizam frente as modificações ocorridas, do que foi deixado devido ao ingresso no mestrado. Nesse sentido, os custos sociais, pessoais e financeiros manifestam-se como elementos preponderantes no pensamento dos alunos, e a noção do processo de formação da pós-graduação e das modificações relacionadas a vida pessoal e profissional são elementos a serem observados por alunos do stricto sensu.

Os relatos fortificam as discussões de Levecque, Anseel, De Beuckelaer, Van der Heyden e 
Gisle (2017) que caracterizam a pós-graduação como um ambiente multitarefas, complexo e que exerce pressão sobre os discentes. Rezende et al. (2017) apontam que as modificações advindas da dificuldade em compatibilizar as obrigações dos estudos com a vida pessoal e fatores psicológicos, como a falta de motivação dos discentes, afeta o desempenho acadêmico e maximizam o nível de stress dos estudantes. Tais preocupações são relevantes, visto que a pós-graduação nem sempre proporciona os retornos financeiros desejados (Barth, 2015). Lidar com essa situação e estar ciente do funcionamento do ambiente acadêmico torna-se importante para aqueles que planejam ingressar nos programas de pósgraduação stricto sensu. Assim, almejou-se identificar os fatores que motivaram esses estudantes a ingressarem no mestrado.

\subsection{Fatores Motivacionais para o Ingresso no Mestrado}

A partir dos construtos definidos no Quadro 1, os alunos foram questionados se alguns fatores influenciaram a decisão de cursar o mestrado. O Quadro 10 apresenta os Discursos Coletivos construídos para alguns fatores motivacionais.

\begin{tabular}{|c|c|c|c|}
\hline 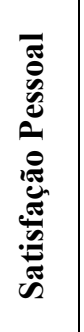 & $\begin{array}{l}\text { Influenciou, porque sempre quis ser docente e } \\
\text { trabalhar em um ambiente onde tivesse a liberdade } \\
\text { de produzir coisas, discutir, aprender e evoluir. } \\
\text { Quando estava trabalhando possuía uma boa } \\
\text { remuneração, mas a satisfação pessoal não era } \\
\text { como eu gostaria. Então, decidi ingressar no } \\
\text { mestrado para que pudesse abrir portas e trabalhar } \\
\text { naquilo que sempre quis. }\end{array}$ & 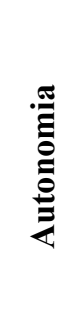 & $\begin{array}{l}\text { Acredito que nem tanto a autonomia, } \\
\text { porque eu sabia que seria capaz de lidar e } \\
\text { dar conta do mestrado. Eu queria aprender } \\
\text { mais e ser docente, mas um docente com } \\
\text { mestrado. }\end{array}$ \\
\hline 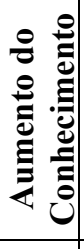 & $\begin{array}{l}\text { Apesar de ser uma consequência do processo, eu } \\
\text { sempre tive essa sede de saber. Vim para o } \\
\text { mestrado com a expectativa de aprender a ser } \\
\text { docente, de aprender coisas novas, com pessoas } \\
\text { diferentes e trocar experiências. }\end{array}$ & $\underset{\mathscr{e}}{\mathscr{0}}$ & $\begin{array}{l}\text { A remuneração não foi um determinante } \\
\text { para o ingresso no mestrado. Mas é algo } \\
\text { muito apreciado, você estudando e } \\
\text { ganhando R\$ } 1.500,00 \text { e as universidades } \\
\text { pagando } 4,6 \text { ou } 8 \text { mil reais, com certeza é } \\
\text { algo que motiva. }\end{array}$ \\
\hline 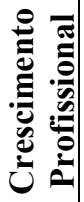 & \multicolumn{3}{|c|}{$\begin{array}{l}\text { Depende, pensando na docência com certeza, porque o mestrado é importante para se atualizar e crescer } \\
\text { intelectualmente e algumas instituições priorizam o mestrado. Agora do ponto de vista empresarial, em } \\
\text { alguns lugares você tem a possibilidade de maior crescimento profissional do que na docência. }\end{array}$} \\
\hline
\end{tabular}

Fonte: Dados da pesquisa.

Lorenzo cita que cursar o mestrado foi totalmente uma escolha influenciada pela satisfação pessoal, pois " [...] tinha muitas outras opções, eu escolhi estar aqui”. Já Davi destaca que nunca refletiu sobre até que ponto esse fator foi determinante, contudo, aponta que "[...] foi uma escolha que eu fiz não em função de uma falta de emprego ou da minha situação atual, mas foi uma escolha porque eu queria fazer". O desejo pela docência é o fator mais destacado entre os alunos. A busca pelo grau de mestre justifica-se pela exigência da proporção mínima de mestres nas instituições universitárias. Nesse sentido, a decisão de cursar o mestrado é influenciada também por fatores externos, ou seja, apesar do anseio em lecionar ser uma motivação intrínseca, há a exigência da titulação para o ingresso em algumas instituições, assim há também influências extrínsecas nessa decisão. Logo, as motivações não são excludentes, mas complementares entre si.

De modo adicional, foi questionado se o anseio por superar novos desafios (efetividade) interferiu na escolha. Arthur afirmou que "sim [...]. Acho que o maior fator disso, é a diferença da graduação, [..] é se sentir desafiado". Da mesma forma, Davi comentou que "sim, [...] buscar o diferente, o novo, também foi um fator bem pertinente". Já Laura admitiu que optou por ingressar no 
programa motivada pelo desejo de praticar à docência, pois não tinha noção do que era abordado no mestrado "eu nem sabia o que era o mestrado (risos). Eu fui saber o que era o mestrado quando eu entre no mestrado. Fui construida no mestrado."

Em relação ao desejo de provar a si mesmo a sua capacidade (autonomia), somente dois entrevistados afirmaram que foi um fator motivacional. O Discurso Coletivo alinha-se as observações de Borges, Faria e Gil (2007) no qual os mestrandos acreditam na sua capacidade de cumprir as tarefas no tempo correto e com eficiência. Percebe-se que as motivações intrínsecas abordadas pela Teoria da Autodeterminação, verificadas por meio dos questionamentos embasados por Avelino, Cunha e Nascimento (2013), Barth, Ensslin e Borgert (2016) e Durso et al. (2016) influenciaram a decisão dos mestrandos pela escolha do mestrado. Em relação aos achados de Avelino, Cunha e Nascimento (2013) os relatos colaboram com a perspectiva de que os alunos consideram aspectos além dos relacionados com o mercado de trabalho para cursar mestrado.

No que concerne a motivação extrínseca, por primeiro foi abordado o tópico da imposição, no qual instigou-se o seguinte questionamento: sua decisão (de cursar o mestrado) foi influenciada por algum tipo de exigência do mercado profissional que você atua ou pretende atuar? Em resposta, Sophia citou que no mercado empresarial privado "o mestrado é exigência zero, pelo contrário, se eu tentar voltar para essa área, com o mestrado possivelmente não vão me contratar, porque o meu salário vai ser muito mais alto do que estão dispostos a pagar".

Da mesma forma, Valentina afirmou que "eles (mercado privado) não veem com bons olhos um mestrado acadêmico. Pelo menos [...] as empresas que eu trabalhei não veem tão com bons olhos o mestrado acadêmico". Em concordância, o relato de Lorenzo confirma que as empresas que não são voltadas para área de ensino não valorizam o mestrado acadêmico, pois no local em que ele trabalhava houveram pressões no sentido de desmotivá-lo a realizar o mestrado, "porque a empresa em que eu trabalhava, [...] mandou eu escolher: ou você faz mestrado, ou você trabalha aqui, as duas coisas não dá". Como exceção, Manuela expõe que foi incentivada a cursar o mestrado e na empresa que trabalhava mantiveram a vaga de emprego "(disseram que) quando eu voltasse teria o meu emprego seguro, iriam me receber de novo. Então, foi muita motivação para mim, que eu sei que quando eu voltar eu já tenho o meu emprego para começar de novo".

Essas evidências mostram que nem sempre o mestrado acadêmico é visto como uma titulação relevante no mercado privado. Sendo importante observar esses aspectos ao decidir ingressar no programa, pois o desenho da carreira profissional pode ser desenvolvido a partir dessa titulação.

Ao serem questionados se o status do título de mestre influenciou a escolha, somente um participante afirmou que foi influenciado. Diante disso, nota-se que há uma questão de satisfação pessoal e de autoestima. Em relação a esse contexto, Miguel declarou que "eu acho que o título de mestre é mais status para mim, enquanto eu saber que sou mestre do que para as outras pessoas. Em geral, eu não vejo as pessoas dando tanta importância assim para o mestre”. Nessa mesma perspectiva, Laura cita que "[...] não diria que fosse status sabe, eu diria que eu queria ser mestre. Na minha instituição tinham quatro professores que não eram mestres e eu era um dos quatro. Então eu me sentia inferior $[\ldots] "$.

Quando questionados se a possibilidade de maximização da remuneração futura influenciou na decisão, Sophia afirmou que foi "um fator secundário ou até terciário". Já Davi expôs que "foi um dos fatores mais relevantes".

O fator remuneratório foi utilizado durante o mestrado, pela Laura como um meio de automotivação. Contudo, a perspectiva da remuneração deve ser observada com parcimônia, visto que não se pode garantir aumentos de renda a partir da titulação de mestre, como observado por Barth (2015). Quando questionados se a possibilidade de crescimento profissional influenciou de alguma forma, 11 respondentes afirmaram positivamente que este fator pesou no momento da tomada de decisão Para o Arthur há fatores impositivos que também pressionam para que o crescimento profissional seja influenciado pelo mestrado. Em contrapartida, Isabella destaca que esse fator não é relevante, pois em algumas situações o mercado privado oferece opções de crescimento profissional mais abrangentes.

Por fim, os entrevistados foram questionados se algum outro fator influenciou a decisão de 
cursar o mestrado. Dessa forma, obtiveram-se as respostas no Quadro 11. Os relatos indicam que a família e os professores da graduação influenciam na decisão de cursar o mestrado. Assim, confirma-se a evidência de Durso et al. (2016) de que alunos que participaram de iniciação científica tem mais propensão para cursar o mestrado.

\section{Quadro 11 - Outros fatores motivacionais}

Alice: Na verdade, assim, [...] estudar e aprofundar também é parte da minha espiritualidade, entendeu?!

Laura: Não tenho ninguém da família que tenha feito mestrado, não tenho ninguém da família que tenha estudado, sabe? É carreira solo, eu poderia dizer que teve interferência. Outros fatores, eu poderia dizer que foram os professores que tive (na graduação).

Sophia: Os meus avós eles são semianalfabetos [...]. A minha mãe estudou até a quarta série, e o meu pai até a quinta série. De mestrado, não tem ninguém fazendo isso, então assim para mim, para a minha história, concluir um mestrado é como se fosse um marco histórico no nome da minha família né. [...] fazer o mestrado é de uma forma ou de outra dizer que eu fui muito mais além do que eles (pais) sonharam.

Valentina: Não, acho que foi principalmente a questão do conhecimento, a qualidade de vida e relacionado a essa carreira (docência).

Isabella: Sim. Acho que até uma questão importante, porque a primeira coisa que me levou a querer tentar o mestrado foi na graduação, onde os professores me incentivaram a entrar na iniciação cientifica.

Manuela: Uma questão de desafio também. [...] acho que mais ou menos aquela coisa que foi falado de provar a mim mesmo que eu podia né.

Lorenzo: Era a vontade de conhecer como que era, ter mais condições de dar aula, e ser professor, basicamente era isso né. Eu achava que o mestrado era isso, aprender a ser professor, ser mestre.

Fonte: Dados da pesquisa.

Para identificar a percepção quanto ao planejamento para ingressar no stricto sensu, foi questionado se os entrevistados fariam algo diferente frente ao planejamento de ingressar no curso. $\mathrm{O}$ Quadro 12 apresenta as percepções de alguns entrevistados.

\section{Quadro 12 - Ingresso no mestrado}

Miguel: Teria publicado menos artigos "ruins". Mas daí eles funcionaram para o que precisavam funcionar na época da minha seleção. [...] e na época a gente não tem conhecimento, faz parte do nosso crescimento acadêmico hoje.

Arthur: Sim, acho que sim. Estudado mais, teria me preparado mais realmente.

Laura: Ah teria, teria prestado mais atenção nas aulas de inglês, teria me dedicado muito mais, me dedicado muito mais, teria feito bastante coisa diferente, teria vindo muito mais preparada.

Manuela: Eu acho que não. Não.

Fonte: Dados da pesquisa.

Por fim, foi perguntado aos participantes se fariam algo diferente durante a sua trajetória no programa, ou seja, após o ingresso. Nesse contexto, Arthur afirmou que "[...] reconhecer os seus limites, é importante também. Você ter noção do trabalho que consegue fazer, saber trabalhar em grupo, saber colaborar, saber utilizar as habilidades que cada um tem [...] e saber administrar o tempo também, [...]. " Da mesma forma, Laura cita que "teria me dedicado um pouco mais, apesar que isso é quase impossivel. [...] eu poderia ter extraido mais coisas, porque eu poderia ter aproveitado melhor o meu tempo, não teria prorrogado por muito tempo as coisas." Ainda em relação ao contexto acadêmico, Helena expõe que "poderia ter participado mais das aulas, ter contribuído mais, falado mais", pois isso de alguma forma influencia na avaliação da disciplina e no desemprenho do aluno.

Sob outra perspectiva, o Davi defende que teria "me aproximado de algumas pessoas, e talvez 
me distanciado de outras", e dentro desse aspecto, o participante advoga que a divisão dos alunos em salas diferentes de acordo com as linhas de pesquisa afeta o convívio entre os acadêmicos. Helena assegura que teria "talvez, tentado distribuir melhor o meu tempo. Não me cobrar tanto [..] deveria ter lidado com mais maturidade". Assim, diversos fatores e fatos influenciam a decisão de ingressar no mestrado. Observa-se, que apesar de todas as dificuldades, pressões, mudanças e limitações, os acadêmicos, em sua maioria, afirmam que não se arrependem de ter ingressado no curso. Nesse sentido, alguns participantes expuseram que o mestrado amplia o olhar e a capacidade de pensar e refletir sobre questões pessoais e profissionais, e que isso reflete seu comportamento na sala de aula. Para Sophia "[...]fazendo uma análise assim, do salto que eu dei nesse um ano e meio, é fantástico", pois "[...] essa questão da superação: o objetivo inicial não era esse, mas fiquei muito feliz de perceber o que está acontecendo" relacionado a ampliação da desenvoltura e do nível de conhecimento.

Da mesma forma, Laura expõe que "a mesma Laura que entrou no mestrado, não é a mesma [...] que hoje está aqui", já que notaram-se modificações até mesmo na desenvoltura em sala de aula, "hoje quando você vai ensinar alguém, você vai ver se aquilo realmente existe, se é dessa forma que tem que ser, busca a essência daquele termo", e isso reflete "quando o aluno faz uma pergunta, você sabe o porquê daquilo, você sabe de onde vem, você consegue referenciar os principais pesquisadores que falam sobre aquilo".

Logo, observou-se que as modificações e os fatores motivacionais são amplos, e que há uma série de elementos que influenciam desde a sua intenção de ingressar no programa, suas vivências, comportamentos e desempenho. Não há variáveis que possam delimitar tais aspectos, assim tem-se a necessidade de aprimorar os elementos de apoio aos alunos, para que se adaptem, e que não sejam afetados psicologicamente ou fisicamente comprometendo sua saúde e até mesmo o desempenho acadêmico. As ações humanas são motivadas a partir de diversos elementos intrínsecos e extrínsecos (DECY; RYAN, 1985). Saber equilibrar as tarefas do mestrado com as demais atividades é importante para que o bem-estar do mestrando permaneça estável.

Planejar rotinas de estudo, compartilhar experiências e técnicas para organização do tempo são ações que podem auxiliar na adaptação ao ambiente stricto sensu. A docência apresenta-se como elemento preponderante na motivação dos discentes, sendo que importante que os programas de pósgraduação priorizem além da pesquisa, a formação de habilidades voltadas para a docência. $O$ fator financeiro corporiza as principais inseguranças dos mestrandos frente a continuidade no curso. Tornase importante a manutenção de políticas de apoio estudantil que forneçam bases sólidas para que os discentes possam concluir o curso, minimizando o risco de evasão, como investigado por Barth (2015).

\section{Considerações Finais}

Os fatores motivacionais, as modificações ocorridas na vida dos ingressantes em cursos de mestrado e o ambiente do stricto sensu têm sido apontados como elementos capazes de afetar a propensão dos discentes na finalização do curso. Direcionando olhares para esta temática, a pesquisa buscou identificar as modificações (sociais, financeiras e psicológicas) que ocorreram na vida dos mestrandos após o ingresso no curso e os fatores que motivaram esses alunos a cursar pós-graduação em contabilidade. Os resultados apontam que o padrão de vida e o comportamento dos alunos foram modificados de modo considerável após o ingresso no programa e que as motivações para cursar o mestrado advêm de fatores intrínsecos e extrínsecos.

As preocupações pairam nos impactos psicológicos negativos que tais mudanças podem ocasionar na vida dos mestrandos, despertando nos alunos preocupações que agravam a ansiedade e comprometem o desempenho no curso. Para o bom andamento do mestrado é importante que os discentes planejem e organizem seu tempo para que consigam dedicar-se as outras atividades pessoais e sociais externas ao mestrado. Pois assim, seu comportamento e autoestima não serão impactados de modo que comprometa seu desempenho e conclusão do curso.

A importância do fator financeiro apresenta-se como elemento a ser observado tanto pelos programas como pelos discentes, pois a falta destes recursos financeiros fomenta a evasão. Nota-se a 
necessidade dos pós-graduandos se planejarem financeiramente antes de ingressarem no curso ou possuírem renda e/ou ainda aportes financeiros externos, devida a limitação do valor da bolsa de estudos. Sob a perspectiva dos programas de pós-graduação tem-se a necessidade da ampliação dos recursos financeiros destinados a manutenção dos discentes ou a adaptação das normativas de bolsas de estudos e atividades para que estes possam obter renda externa.

Diferentemente do apregoado pela Teoria do Capital Humano as introspecções apontam que cursar o mestrado não garante maximização financeira, dependendo de desdobramentos que ocorrerão na carreira do indivíduo, sendo um ponto a ser explorado em estudos futuros. Os achados ainda revelam a ausência de um número mais elevado de disciplinas e ações que incentivem e desenvolvam a prática da docência e o aperfeiçoamento da didática. Seguir a carreira docente está entre os principais fatores motivacionais do discente, contudo, nota-se que a atenção do curso de pós-graduação está direcionada para aspectos relacionados a pesquisa. Um dos motivos para essa falta de alinhamento pode estar nos critérios de publicação científica utilizados pela CAPES para avaliar os programas de pós-graduação brasileiros, pois há enfoque mais elevado na produção científica, do que na formação docente.

Considera-se que esse trabalho tenha dado voz aos mestrandos, de modo a mostrar as modificações que ocorrem na vida daqueles que almejam a titulação de mestre e as motivações que os levaram a cursar o mestrado. Espera-se que as discussões aqui expostas auxiliem na gestão dos alunos de programas de pós-graduação, bem como seja fonte de consulta para aqueles que desejam ingressar no mestrado.

Ressalta-se que esse estudo é reflexo do desenho da pós-graduação existente no Brasil, sendo que os aspectos evidenciados podem servir de sinalização para os órgãos de fomento redesenhar os programas de pós-graduação, e auxiliar no desenvolvimento de políticas de manutenção estudantil. O enfoque do estudo foi voltado para as modificações, motivações e dificuldades passadas por aqueles que cursam o mestrado, pois ao analisar as motivações de estudos existentes realizados com graduandos, percebe-se elevadas expectativas por parte destes alunos em relação a titulação de mestre. Nesse sentido, quando se discute o ingresso na pós-graduação stricto sensu deve-se observar os pontos positivos e negativos, sendo importante ter conhecimento dos dois lados dessa mesma história.

Por fim, pesquisas futuras podem verificar em outras áreas do conhecimento ou instituições, bem como em mestrados profissionais tais modificações e fatores motivacionais. As limitações do estudo abarcam-se em sua abordagem metodológica, pois há poucos estudos qualitativos inerentes a temática na área de Ciências Sociais Aplicadas dificultando a comparação de evidências. Entretanto, os pesquisadores acreditam que essa seja uma das principais contribuições da pesquisa.

\section{Referências}

ANDERE, M. A.; ARAUJO, A. M. P. DE. (2008). Aspectos da formação do professor de ensino superior de Ciências Contábeis: uma análise dos programas de pós-graduação. Revista Contabilidade \& Finanças-USP, v. 19, n. 48, p. 91-102. https://doi.org/10.1590/s1519-70772008000300008

ANDRADE, D. V. P.; VASCONCELOS, N. V. C. DE; MACEDO, D. M. DE; QUEIROZ, J. V.; QUEIROZ, F. C. B. P. Um Estudo sobre Motivação, Expectativas e Influências dos Mestrandos em Engenharia de Produção da UFRN. In: VIII Simpósio de Excelência em Gestão e Tecnologia, Resende, Rio de Janeiro, 2011, Anais..., 2011.

AVELINO, B. C.; CUNHA, J. V. A. DA; NASCIMENTO, E. M. Desenvolvimento profissional de estudantes de Ciências Contábeis: análise empírica sobre as intenções após a graduação em relação a cursar pós-graduação. Revista Universo Contábil, v. 9, n. 2, p. 104-124, 2013.

DOI:10.4270/RUC.2013215

ARAÚJO, M. S. T. DE; AMARAL, L. H. Motivação dos candidatos ao mestrado profissional em ensino de ciências e matemática da UNICSUL. XVI Simpósio Nacional de Ensino de Física, Rio de Janeiro, 2005, Anais..., 2005.. 
BARDIN, L. Análise de conteúdo. Lisboa: Edições 70, 1977.

BARTH, T. G. A relação custo-benefício socioeconômica da pós-graduação stricto sensu: uma análise na percepção de mestres em contabilidade. Dissertação (mestrado) - Universidade Federal de Santa Catarina, Centro Sócio- Econômico, Programa de Pós-Graduação em Administração, Florianópolis, 2015.

BARTH, T. G.; ENSSLIN, S. R.; BORGERT, A. Os Benefícios Pessoais da Pós-Graduação Stricto Sensu: uma Análise na Percepção de Mestres em Contabilidade. REPeC - Revista de Educação e Pesquisa em Contabilidade, v. 10, n. 1, p. 106-128, 2016. https://doi.org/10.17524/repec.v10i1.1326

BECKER, G. S. Investment in Human Capital: A Theoretical Analysis. Journal of Political Economy, v. 70, n. 5, p. 9-49, 1962.

BERLYNE, D. E. Novelty and curiosity as determinants of exploratory behavior. British Journal of Psychology, v. 41, p. 1, p. 68-80, 1950. https://doi.org/10.17524/repec.v10i1.1326

BORGES, T. N.; FARIA, A. C. DE; GIL, A. DE L. Ensaio teórico sobre os fatores críticos de sucesso e pontos de falha do processo de gestão dos mestrandos em contabilidade: a ótica da metodologia DEQ. REPeC - Revista de Educação e Pesquisa em Contabilidade, v. 1, n. 3, p. 63-82, 2007. https://doi.org/10.17524/repec.v1i3.16

CASA NOVA, S. Entre-vistas - planejamento, condução e análise de entrevistas. XX in: Seminário de Administração, Universidade São Paulo - USP, São Paulo, 09 nov., 2017.

CARVALHO, D. M.; AMICCI, F. L.; ANDRADE, J.; KATZ, S. Atitudes e opiniões dos alunos da FEA-USP quanto a cursar pós-graduação. In: VI SEMEAD - Seminários em Administração, São Paulo, São Paulo, 2003. Anais..., 2003.

COOPER, D. R.; SCHINDLER, P. S. Métodos de pesquisa em administração. (10. ed.) Porto Alegre: Bookman, 2011.

CUNHA, J. V. A. da. Doutores em Ciências Contábeis da FEA/USP: análise sob a óptica da Teoria do Capital Humano. Tese (doutorado) - Universidade de São Paulo, Departamento de Contabilidade e Atuária da Faculdade de Economia, Administração e Contabilidade - FEA, São Paulo, 2007.

DECI, E. L. The psychology of self-determination. Lexington, Mass.: D. C. Heath (Lexington Books), 1980.

DECI, E. L.; RYAN, R. M. The empirical exploration of intrinsic motivational processes. In L. Berkowitz (Ed.), Advances in experimental social psychology (13, 39-80). New York: Academic, 1980. https://doi.org/10.1016/s0065-2601(08)60130-6

DECI, E. L.; RYAN, R. M. Intrisic motivation and self-determination in human behavior. Spring Street: New York, 1985.

DECI, E. L.; RYAN, R. M. Self-Determination Theory and the Facilitation of Intrinsic Motivation, Social Development, and Well-Being. American Psychologist, v. 55, n. 1, p. 68-78, 2000. https://doi.org/10.1037//0003-066x.55.1.68

DURSO, S. DE O.; CUNHA, J. V. A. DA; NEVES, P. A.; TEIXEIRA, J. D. V. Fatores Motivacionais para o Mestrado Acadêmico: uma Comparação entre Alunos de Ciências Contábeis e Ciências 
Econômicas à luz da Teoria da Autodeterminação. Revista Contabilidade e Finanças, v. 27, n. 71, p. 243-258, 2016. https://doi.org/10.1590/s1519-70772013000200007

FREDERICO-FERREIRA, M.; LOUREIRO, C. (2013). Motivos para a procura de mestrados: estudo exploratório com enfermeiros. Revista de Enfermagem Referência, v. 9, n. 3, p. 67-74. https://doi.org/10.12707/riii1264

FREUD, S. On narcissism. In The standard edition of the complete works of Sigmund Freud (14). London: Hogarth Press, 1914.

HARLOW, H. F. Learning and satiation of response in intrinsically motivated complex puzzle performance by monkeys. Journal of Comparative and Pshysiological Pychology, v. 43, n. 4, p. 289-294. https://doi.org/10.1037/h0058114

HULL, C. L. Principles of behavior: An introduction to behavior theory. New York: AppletonCentury-Crofits, 1943.

IWAMOTO, H.; TAKAHASHI, M. A Quantitative Approach to Human Capital Management. Procedia - Social and Behavioral Sciences, v. 172, p. 112-119, 2015.

https://doi.org/10.1016/j.sbspro.2015.01.343

LEI No 9.394, DE 20 DE DEZEMBRO DE 1996. Estabelece as diretrizes e bases da educação nacional, 1996.

LEITE FILHO, G. A.; RODRIGUEZ, F. C. Atitudes e opiniões dos alunos do curso de graduação em Ciências Contábeis quanto a cursar pós-graduação: um estudo numa universidade pública. UnB Contábil - UnB, v. 9, n. 1, p. 115-149, 2006.

LEVECQUE, K.; ANSEEL, F.; DE BEUCKELAER, A.; VAN DER HEYDEN, J.; GISLE, L. Work organization and mental health problems in PhD students. Research Policy, v. 46, n. 4, p. 868-879, 2017. https://doi.org/10.1016/j.respol.2017.02.008

MARTINS, O. S., \& MONTE, P. A. Motivações, expectativas e influências relacionadas ao título de Mestre em Ciências Contábeis pelo Programa UnB/UFPB/UFPE/UFRN. Contabilidade, Gestão e Governança, v. 13, n. 1, p. 16-31, 2010.

\section{MARTINS, G. A.; THEÓPHILO, C. R. Metodologia da Investigação Científica para} Ciências Sociais Aplicadas, 2 ed. São Paulo: Atlas, 2009.

MASLOW, A. H. A theory of human motivation. Psychological Review, v. 50, p. 370-396, 1943. https://doi.org/10.1037/h0054346

REZENDE, M. S. de; MIRANDA, G. J.; PEREIRA, J. M.; CORNACCHIONE, E. B. Jr. Stress e desempenho acadêmico na pós-graduação stricto sensu em ciências contábeis no Brasil. Archivos Analíticos de Políticas Educativas / Education Policy Analysis Archives, v. 25, p. 96, 2017. https://doi.org/10.14507/epaa.25.2931

RYAN, R. M. Control and information in the intrapersonal sphere: An extension of cognitive evaluation theory. Journal of Personality and Social Psychology, v. 43, p. 450-461, 1982. https://doi.org/10.1037/0022-3514.43.3.450

SAMPIERI, R. H.; COLLADO, C. F.; LUCIO, P. B. Metodologia da Pesquisa. 5. ed. São Paulo: McGraw-Hill, 2013. 
SCHULTZ, T. W. Investment in man: An economist view. The Social Service Review, v. 33, n. 2, p. 109-117, 1959.

SCHULTZ, T. W. O Capital Humano - Investimentos em Educação e Pesquisa. Trad. Marco Aurélio de Moura Matos. Rio de Janeiro: Zahar Editores, 1971.

SHAPIRO, D. Autonomy and rigid character. New York: Basic Books, 1981.

WHITE, R. W. Motivation reconsidered: The concept of competence. Phychological Review, v. 66, p. 297-333, 1959.

\section{Agradecimentos}

Cabe ressaltar e agradecer a participação dos entrevistados Alice, Arthur, Bernardo, Davi, Helen, Isabella, Laura, Lorenzo, Manuel, Miguel, Sophia e Valentina. As pessoas quando aceitam participar de entrevistas e relatar aspectos pessoais estão realizando muito mais que simples relatos, estão entregando e confiando aos pesquisadores parte de suas histórias (CASA NOVA, 2017). Somos gratos por confiarem vossas histórias a nós.

* Artigo apresentado no XX SEMEAD Seminários em Administração, novembro de 2017. 